\title{
Distanze illusorie: l'uso della prospettiva aerea nelle Carceri piranesiane
}

\author{
Sofia Menconero
}

Abstract

La prospettiva aerea in ambito pittorico è resa attraverso la diminuzione della saturazione dei colori, del contrasto tra le parti e della nitidezza dei dettagli. Nell'incisione tale effetto esula dalla componente cromatica e la sua resa dipende molto dalle caratteristiche esecutive delle varie tecniche. In generale, i metodi per ottenere dei gradienti tonali nelle tecniche incisorie riguardano la distanza, l'incrocio e lo spessore dei segni. Quest'ultimo può dipendere dall'uso di punte di diverso spessore o, nel caso dell'acquaforte, dal numero di 'coperture'.

II contributo presenta uno studio sulla prospettiva aerea delle Carceri di Piranesi condotto attraverso la scomposizione delle tavole in piani di profondità. Dallo studio si evince come l'artista veneto abbia fatto uso di questo effetto, che accentua la profondità e che usualmente viene applicato al paesaggio, in ambienti interni per aumentare la monumentalità dell'architettura e illudere l'osservatore di maggiori distanze.

Parole chiave

Piranesi, acquaforte, Carceri, prospettiva aerea, distanza illusoria.
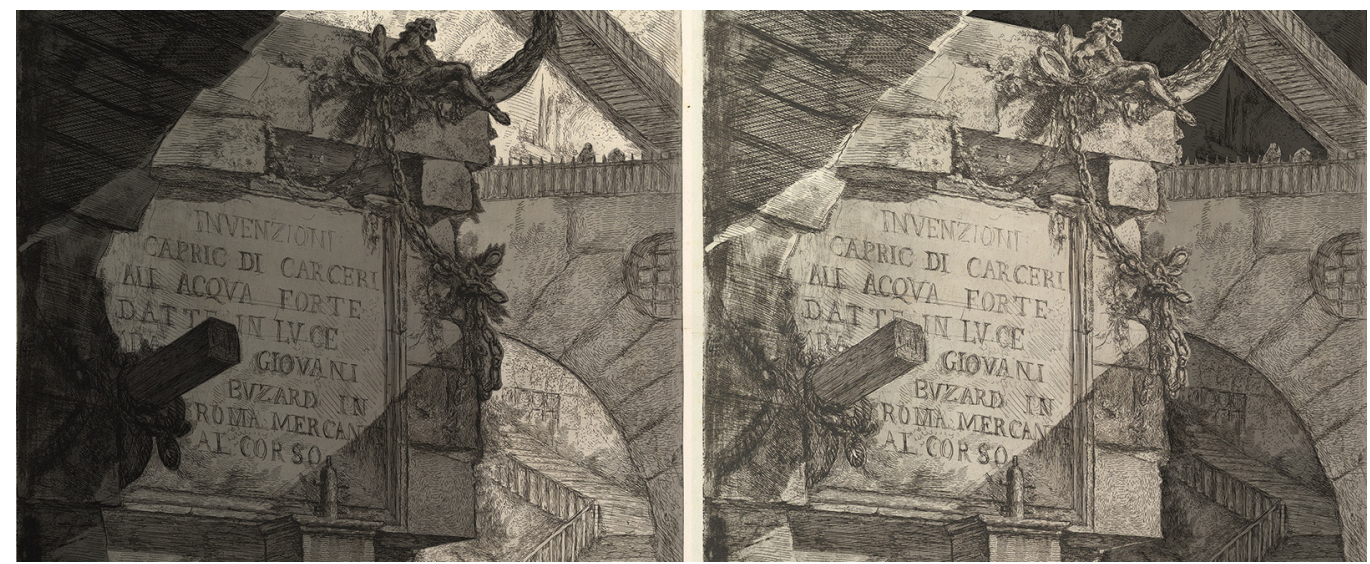


\section{Introduzione}

Giovanni Battista Piranesi a metà del 1700 pubblica la prima edizione delle sue celebri prigioni: le Invenzioni capricciose di Carceri all'acquaforte [Robison 1986, pp. 37-44]. Si tratta di 14 tavole particolarmente suggestive e singolari, incise all'acquaforte, che rappresentano, con il tipico segno libero e brillante della tradizione incisoria veneziana, ampi ambienti caratterizzati da un'architettura antica, massiccia e spazialmente articolata. Mutuando il topos della prigione come cortile o piazza dalla scenografia contemporanea [Gavuzzo-Stewart 1999, pp. 73-74], le Carceri piranesiane sono caratterizzate da una compenetrazione di ambientazioni interne ed esterne [Garms 1982, p. I 19] che esulano dall'apparenza di luoghi di costrizione e di tortura come invece dovevano essere nel XVIII secolo [I].

Ad accentuare la dilatazione dello spazio concorre il trattamento tecnico che Piranesi conferisce ai suoi rami. Nonostante le distanze rappresentate non siano particolarmente ingenti, ma si risolvano all'interno della scala architettonica, egli illude gli osservatori di uno spazio più profondo ricorrendo a una sorta di prospettiva aerea.

A distanza di una decina d'anni dalla prima pubblicazione, Piranesi rielabora i suoi rami ed esce con una nuova edizione dal titolo Carceri d'invenzione [Robison 1986, pp. 45-53]. Questa nuova raccolta conta 16 tavole, per la prima volta numerate e ordinate dall'autore, delle quali due completamente nuove (tavola II e V), una quasi del tutto modificata (tavola $X V I)$, e le altre che presentano variazioni più o meno evidenti. Al di là dell'introduzione di nuovi elementi architettonici e di strumenti di tortura, un'importante differenza tra le due edizioni riguarda l'ampliamento della gamma tonale delle tavole, che conferisce alla versione più tarda maggiori contrasti e una prospettiva aerea ancora più evidente.

II presente contributo, affiancandosi alla numerosa letteratura che onora da secoli l'opera dell'incisore veneto, vuole proporre una riflessione su un aspetto poco indagato: l'uso della prospettiva aerea nelle Carceri piranesiane.

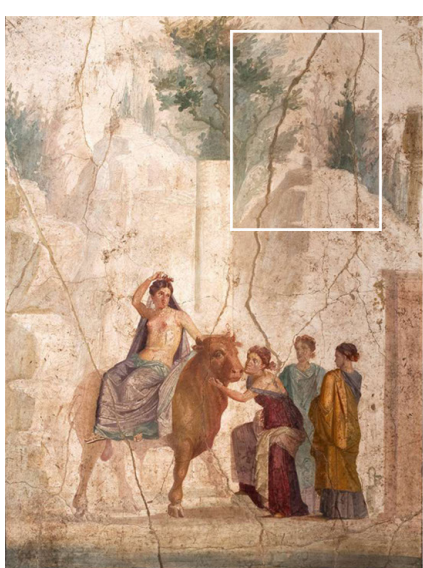

a

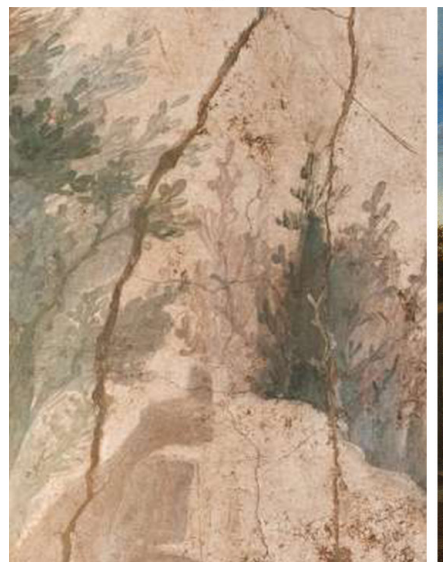

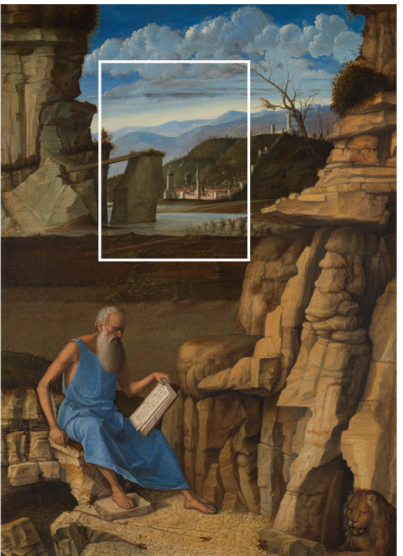

b

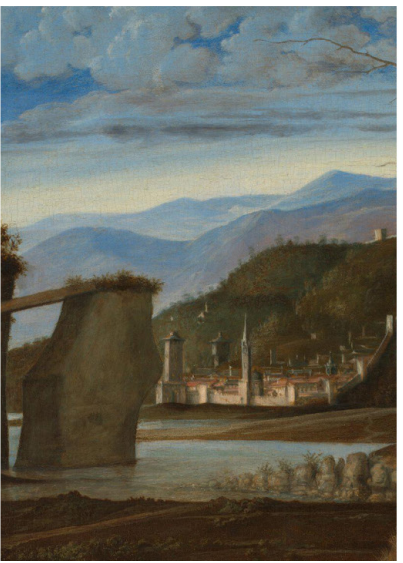

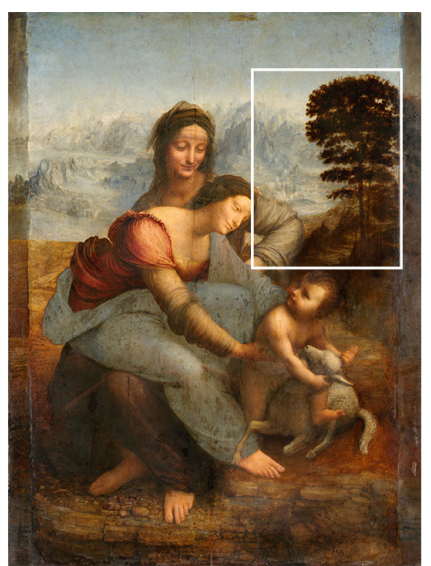

C

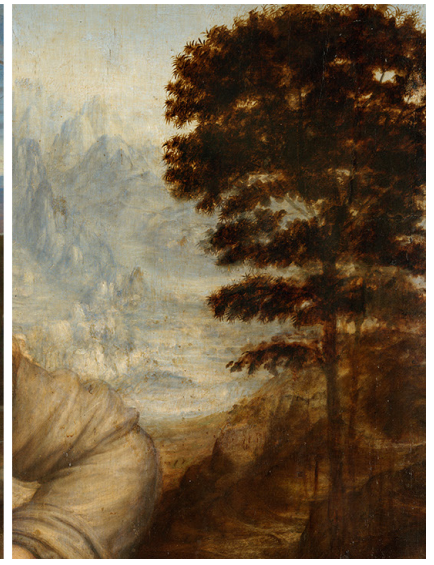

Fig. I. (a) Europa su toro, aftresco pompeiano, 20-25 co Nazionale di Napoli): (b) Giovanni Bellini, S. Girolamo leggente in tavola, I 480-85 (National Gallery, London): (c) LeoGallery, London); (c) Leola Vergine e il Bambino con l'agnellino, olio su tavola, I 503-19 (Musée du Louvre, Paris). 


\section{La prospettiva aerea dalla pittura all'acquaforte}

La prospettiva aerea è uno degli indizi visivi di profondità [Brooks 2017, pp. I-I0]. Essa, insieme ad altri segnali come l'occlusione, la dimensione e la densità relativa, l'altezza del campo visivo, la prospettiva lineare, la parallasse, ecc. permette al cervello di comprendere la localizzazione di un determinato elemento osservato. Si basa sul presupposto che tra l'osservatore e l'oggetto osservato sia presente un'atmosfera composta di particelle che alterano la visione all'aumentare della distanza, la quale influenza la saturazione dei colori, il contrasto tra le parti e la nitidezza dei dettagli [Mancini 20 I5, pp. 29-35].

Nel campo dell'arte, vi sono testimonianze saltuarie dell'intuizione della prospettiva aerea fin dal periodo romano (fig. Ia). Nel Quattrocento italiano si ritorna a farne un uso assiduo (fig. I b), seppure non sia ancora avvenuta la teorizzazione del fenomeno o di una prassi condivisa per ottenerlo, a parte cenni incompleti ad opera di Cennino Cennini [2] nel secolo precedente, e Leon Battista Alberti [3]. II primo a studiare e a definire la prospettiva aerea con il nome con cui oggi la conosciamo è Leonardo da Vinci in una serie di appunti che confluiranno nel postumo Trattato della pittura (I540 ca.) [4]. II Maestro toscano, oltre ad applicarla in modo magistrale (fig. I c), ha il merito di definire vari fenomeni che concorrono all'indizio visivo della profondità: "La prospettiva la quale si estende nella pittura si divide in tre parti principali, delle quali la prima è della diminutione che fanno le quantità de' corpi in diverse distanze. La seconda parte è quella che tratta della diminutione de' colori di tali corpi. La terza è quella che diminuisce la notizia delle figure, e de' termini che hanno essi corpi in varie distanze" [Leonardo da Vinci I65 I, p. I04- I05].

L'effetto cromatico della distanza sarà ripreso e approfondito da Matteo Zaccolini in De colori [Guidolin 2015] e in Prospettiva del colore (1622) [Bell 1993], e tradotto in termini matematici da Johann Heinrich Lambert in Sur la perspective aërienne (1774) [Mancini 20 I5, pp. | | 3- | | 5]. || felice connubio tra la scienza della geometria proiettiva e l'arte del colore avrà, specialmente nel XVII secolo con Andrea Pozzo, le sue applicazioni più interessanti in termini di architettura illusoria [Amoruso, Firenze 20 I4; Mancini 20I5].

Fig. 2. (a) Albrecht Dürer, Mulino, acquarello e guazzo su carta, 1489zu Berlin); (b) Albrecht zu Berlin); (b) Albrecht Dürer, Festa del Rosario,
olio su tavola, 1506 (Foto (C) National Gallery Prague 2021).
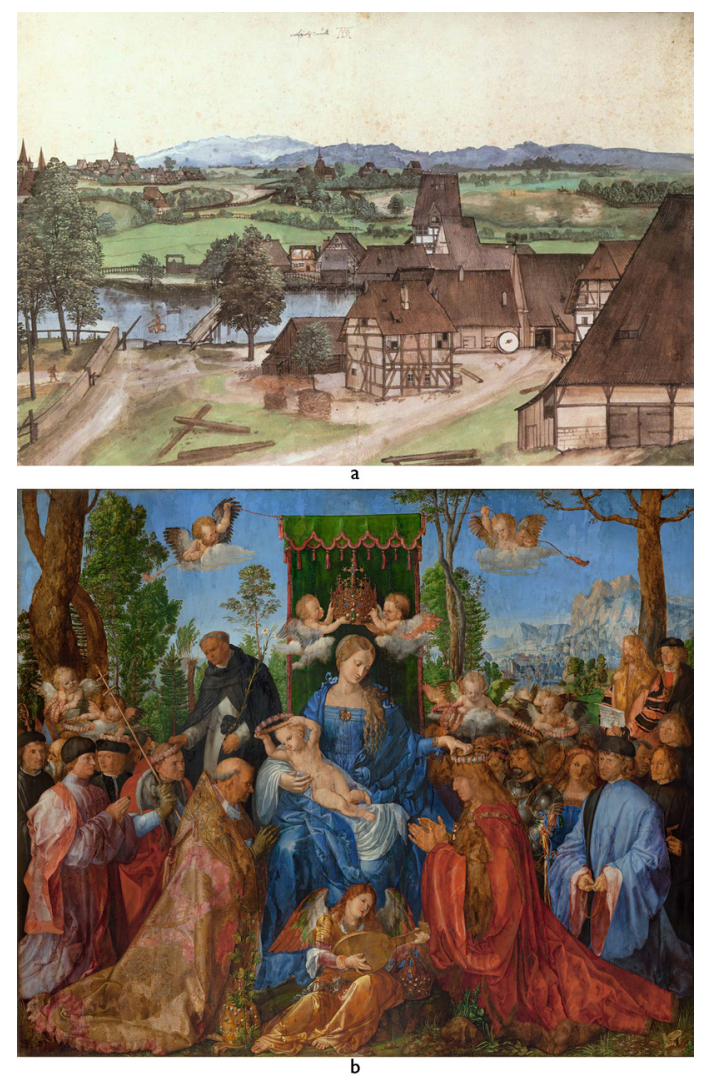
Nella tecnica incisoria, il fenomeno della prospettiva aerea è molto meno studiato rispetto all'arte pittorica. Chiaramente, l'effetto esula dalla componente cromatica e viene reso nei termini di una perdita dei dettagli e variazione tonale (schiarimento) delle zone più lontane della rappresentazione.

I metodi per rendere la prospettiva aerea nelle incisioni sono strettamente legati alla tecnica incisoria utilizzata. A questo proposito, il caso di Albrecht Dürer è particolarmente emblematico perché permette un raffronto della resa della prospettiva aerea condotta da uno stesso autore ma con tecniche diverse, sia pittoriche che incisorie [Panofsky 1967]. Nell'acquerello il Mulino del I 498 ca. (fig. 2a), uno dei primi studi di Dürer, la mancanza di abilità prospettica è parzialmente colmata dall'accenno di una prospettiva aerea sui monti dello sfondo, ottenuta da un progressivo chiarore, da una semplificazione dei particolari e da una tinta sui toni del blu. Rimanendo in ambito pittorico, la Festa del Rosario (fig. 2b), olio su tavola del I506, mostra la splendente ricchezza del colore di influenza veneziana accompagnato da una prospettiva aerea caratterizzata da tinte progressivamente più chiare e in toni di blu. II grado di dettaglio dello sfondo è piuttosto elevato, in accordo con l'accuratezza generale del disegno. Le opere incisorie di Dürer considerate sono un bulino, la Vergine della libellula del I 493 ca. (fig. 3a), e una xilografia degli stessi anni, Sansone che squarta il leone (fig. 3b). Le differenze nel trattamento della prospettiva aerea dipendono principalmente dalle possibilità espressive che le due tecniche permettono: "un incisore tende a essere analitico, dettagliato e concreto quanto uno xilografo tende a essere sinottico, conciso e astratto" [Panofsky 1967, p. 85]. Entrambe le tecniche rendono la prospettiva aerea grazie allo schiarire dei toni e alla perdita di dettagli. L'incisione a bulino mostra in lontananza delle colline meno particolareggiate, rispetto al resto della composizione, di cui si scorgono i contorni e qualche altro tratto di ombreggiatura di ausilio alla comprensione dell'orografia. Nella xilografia le colline sullo sfondo sono rappresentate soltanto attraverso i loro contorni.

In linea generale i metodi per ottenere dei gradienti tonali nelle tecniche incisorie riguardano la distanza e l'incrocio dei segni (fig. 4a), e il loro spessore. Quest'ultimo può dipendere dall'uso di punte di diverso spessore (fig. 4b) o, nel caso dell'acquaforte, dal numero di coperture (fig. 4c). Infatti, questa tecnica di incisione indiretta permette di eseguire, tramite un acido chiamato acquaforte, morsure multiple che saranno tra i motivi della grande varietà tonale delle Carceri piranesiane [Pane 1938, pp. 23, 24].

Fig. 3. (a) Albrecht Dürer Vergine della libellula, bulino (stampa), I 493-97 (Rijksmuseum, Amsterdam) (b) Albrecht Dürer, Sansone che squarta il leone, xilografia (stampa), | 494-98 (Rijksmuseum, Amsterdam).

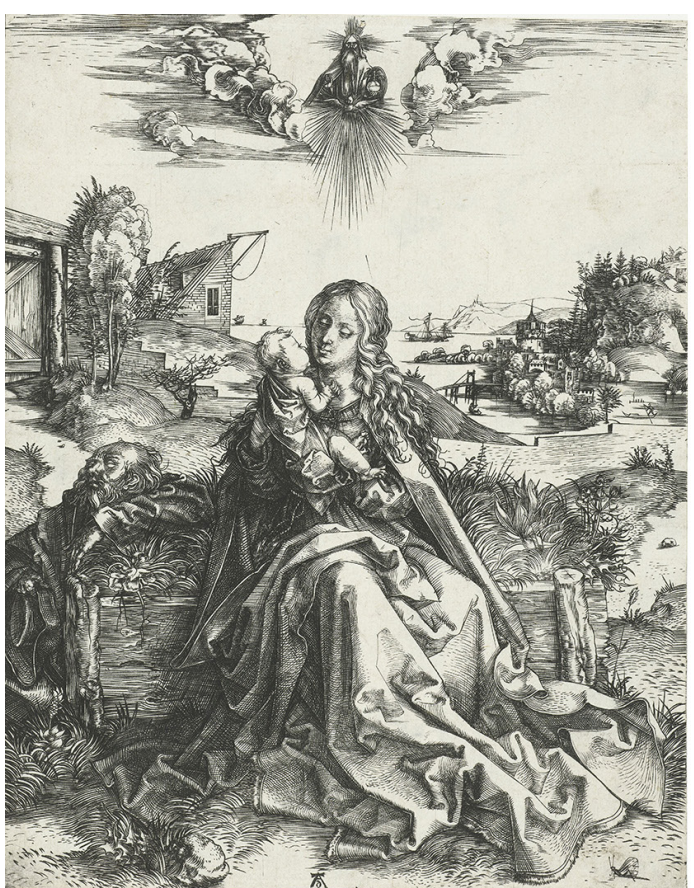

a

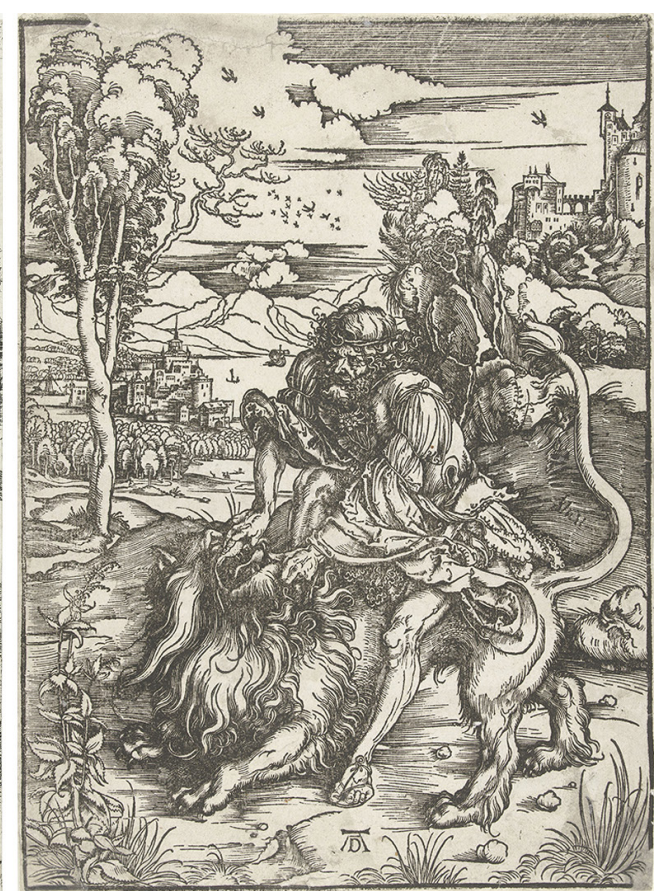

b 
Fig. 4. Giovanni Battista Piranesi, particolari da Tortura di un condannato tavola II delle Carceri

d'invenzione, acquaforte $e$ bulino su rame (matrice) |749-6| (Istituto Centrale per la Grafica, Roma). Varie modalità di resa dei gradienti tonali: (a) segni; (b) punte di diverso spessore: (c) morsure multiple.
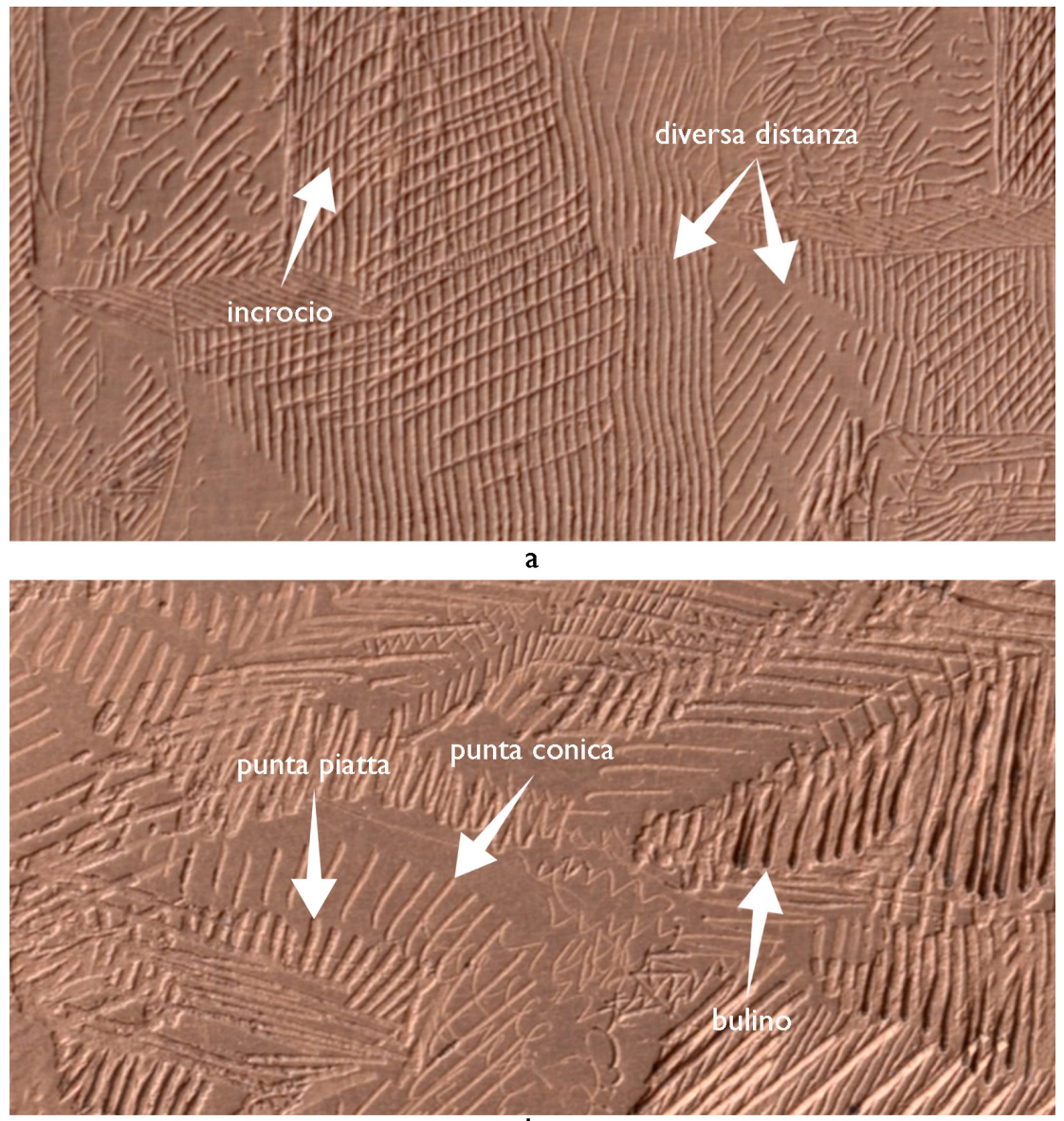

b

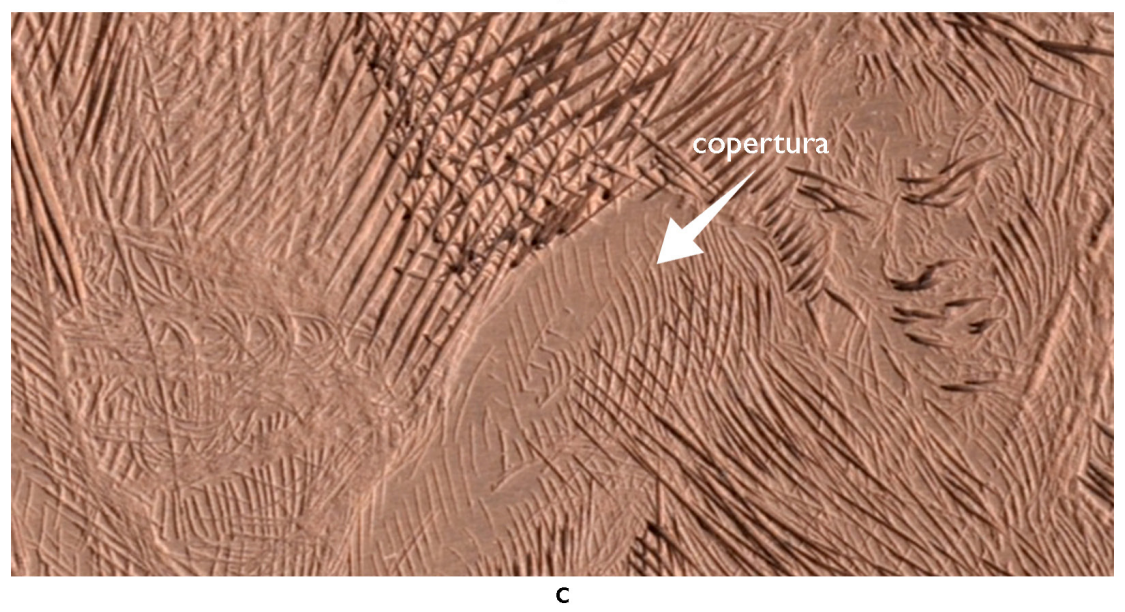

Riflessioni sulla profondità apparente delle Carceri di Piranesi

Le Carceri piranesiane sono prospettive costruite senza il rigore proiettivo che permetterebbe di conoscere gli spazi rappresentati grazie al metodo della restituzione prospettica. Gli spazi si possono, però, interpretare attraverso analisi di altra natura.

Una di queste analisi prevede la scomposizione delle tavole secondo piani di profondità, come fossero quinte o spezzati teatrali, in modo da fornire un'idea orientativa dei rapporti spaziali che intercorrono tra gli elementi rappresentati, almeno in termini relativi. Questa operazione si attua intervenendo dove sono visibili soluzioni di continuità tra gruppi di 
elementi architettonici. La singolare discontinuità delle prospettive delle Carceri era già stata osservata da Sergej Ejzenštejn:"Nelle Carceri noi non troviamo mai una visione prospettica che proceda in profondità senza interruzioni. Ovunque, il movimento prospettico in direzione dello sfondo è interrotto da un ponte, da un pilastro, da un arco, da una galleria. Ogni volta, al di là di quel pilastro o di quell'arco, il movimento prospettico riprende di nuovo. Ma non più nella medesima chiave prospettica, bensì in una nuova: generalmente le proporzioni si riducono molto più di quanto uno si aspetterebbe" [Ejzenštejn 1980, p. I06].

I casi riportati come esempio, che riguardano la prima edizione del frontespizio e della tavola VII, mostrano la suddivisione in cinque piani di profondità.

Nel frontespizio (fig. 5) il primo piano comprende l'arco di pietra che inquadra la tavola nel margine in alto a sinistra. Subito dopo viene il complesso con l'epigrafe e il prigioniero. Ancora più lontano si trova il ponte in pietra sulla destra e la passerella di legno al di sopra. II quarto piano è composto dalla scalinata che si intravede al di sotto del ponte e l'ultimo piano riguarda lo sfondo in alto, verso il cielo.

II primo piano della tavola VII (fig. 6) è ancora un arco, che questa volta inquadra la tavola nell'angolo in alto a destra e dalla cui sommità cala una corda. In secondo piano si trova la grande scala con il pozzo e la parete retrostante. Ancora oltre vi è il ponte in pietra con l'epigrafe e il ponte levatoio in legno. Poi c'è un gruppo di varie architetture, tra cui le due torri
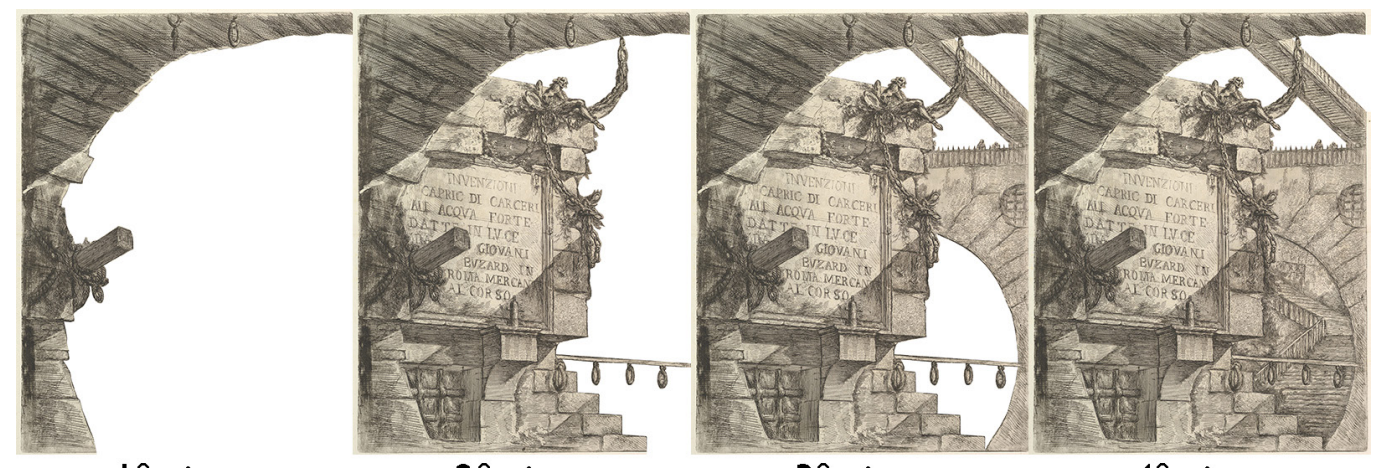

$1^{\circ}$ piano

$$
2^{\circ} \text { piano }
$$

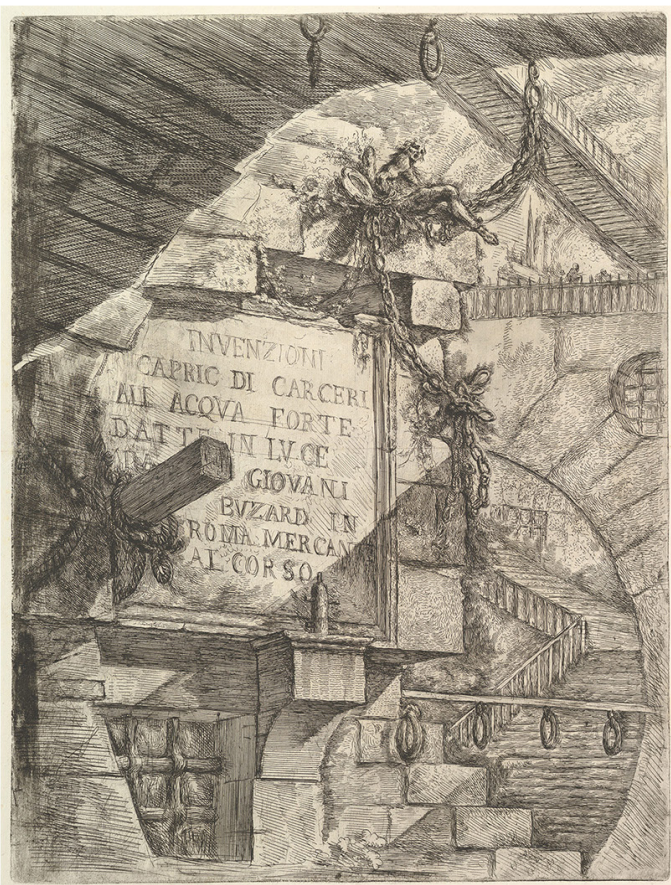

$5^{\circ}$ piano
Fig. 5. Giovanni Battista
Piranesi, Frontespizio

delle Invenzioni

capricciose di Carcer

all'acquaforte, acquaforte

(stampa), 1749-50

(Metropolitan Museum

of Art, Washington):
scomposizione in piani di profondità. 
avvolte dalla scala elicoidale. Infine, uno sfondo che sembrerebbe rappresentare un interno. È possibile estendere questo tipo di studio alle altre tavole della serie: ciò che ricorre è la presenza di un primo piano realizzato tramite un elemento che inquadra la tavola, una sorta di arco di proscenio trattato con toni più scuri rispetto al resto. Un altro elemento che concorre alla definizione dei piani di profondità è il trattamento grafico associato alle varie parti delle immagini. I segni incisi all'acquaforte all'aumentare della profondità diventano meno ravvicinati e meno numerosi, nonché meno definiti.

Per evidenziare e sintetizzare i piani di profondità riscontrati nelle tavole esemplificative è stata creata una figura di sintesi dove a ciascun piano è stata attribuita una luminosità diversa. Nel primo caso (fig. 7) la luminosità assegnata amplifica, ma segue, la prospettiva aerea conferita da Piranesi ed è evidente come, in questo modo, la percezione degli spazi faccia pensare ad ambientazioni esterne. Nel secondo caso (fig. 8) la luminosità è assegnata in modo opposto: i piani diventano più scuri in lontananza, come dovrebbe accadere in ambienti chiusi soggetti ad occlusione ambientale. In questo secondo caso gli spazi risultano percettivamente più piccoli.

Passati dieci anni dalle prime acqueforti, l'incisore riprende le vecchie matrici di rame e le modifica, eliminando e aggiungendo segni [5]. Le stampe che ne derivano sono più contrastate, con scuri più profondi che accentuano ancora di più la prospettiva aerea (fig. 9).

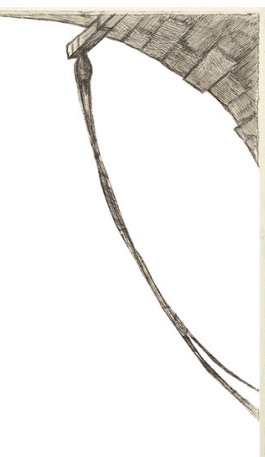

$1^{\circ}$ piano

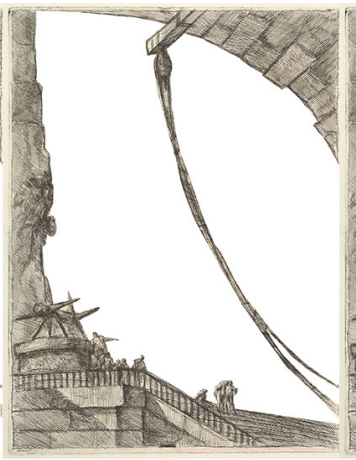

$2^{\circ}$ piano

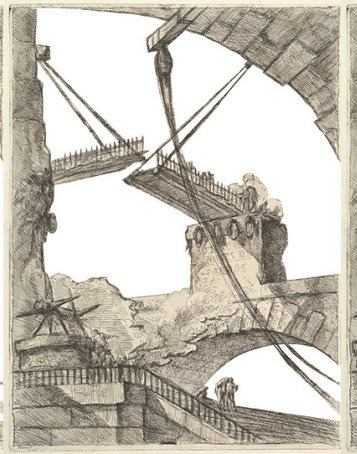

$3^{\circ}$ piano

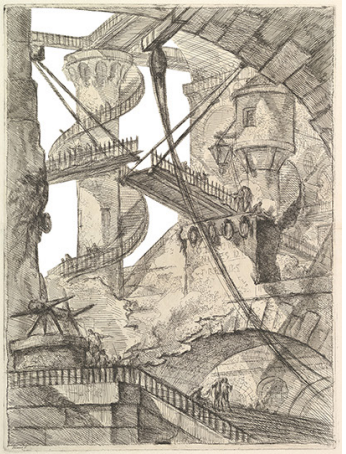

$4^{\circ}$ piano

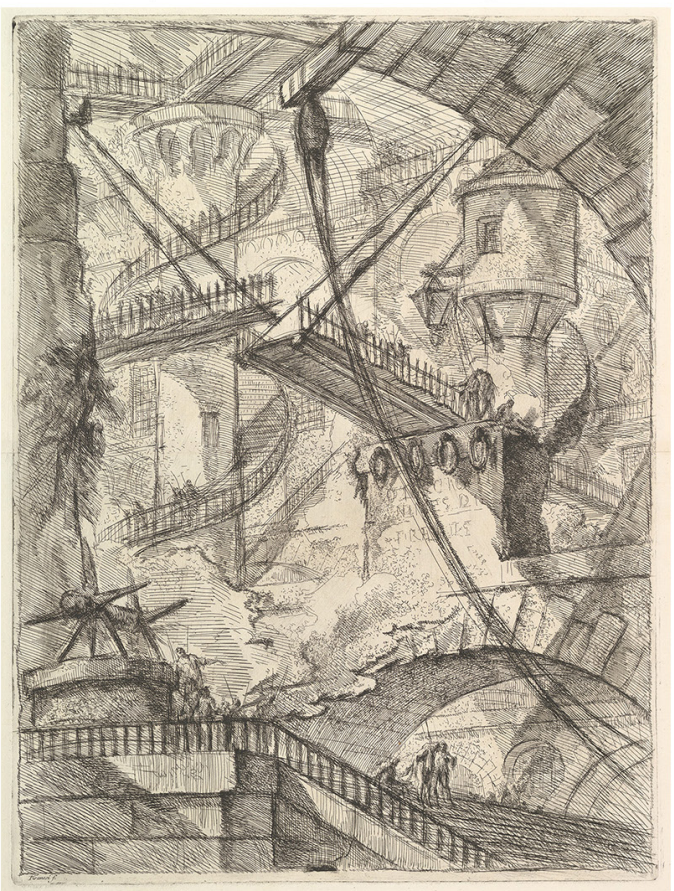

$5^{\circ}$ piano 
Fig. 7. Elaborazione grafica del frontespizio (sinistra) e della tavola VII (destra) delle Invenzioni capricciose di Carceri all'acquaforte. L'elaborazione accentua la prospettiva aerea conferita da Piranesi.

Fig. 8. Elaborazione grafica del frontespizio (sinistra) e della tavola VII (destra) delle Invenzioni capricciose di Carceri all'acquaforte. L'elaborazione mostra l'effetto opposto alla prospettiva aerea conferit da Piranesi.
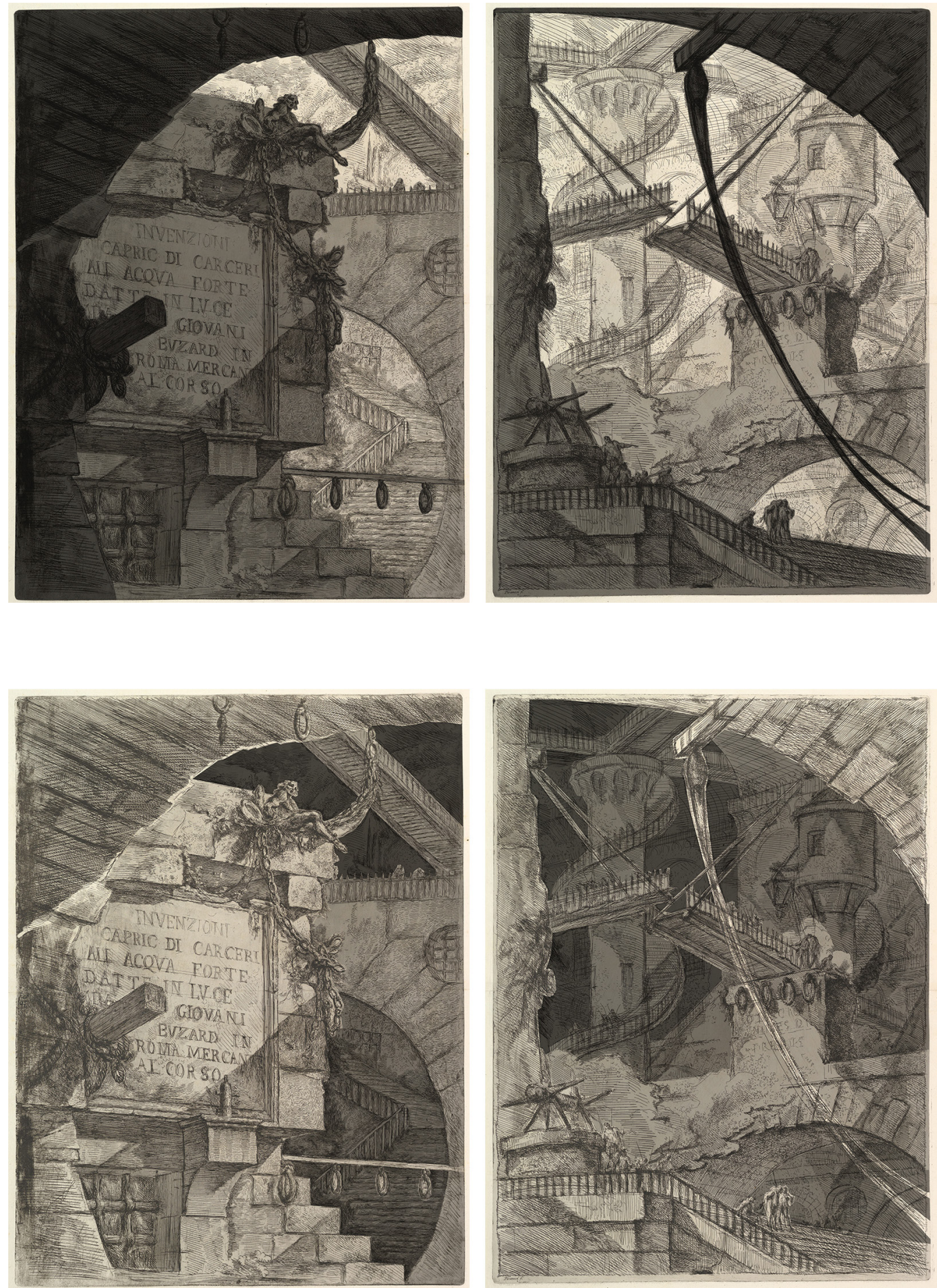


\section{Conclusioni}

L'effetto che Piranesi conferisce alle sue Carceri consiste nell'assegnare toni più chiari all'aumentare della distanza in linea con i principi della prospettiva aerea, anche se si suppone che gli ambienti rappresentino spazi interni, bui e sotterranei, in cui la luce non ha la forza di attraversare grandi distanze. Ciò determina un'incoerenza tra il soggetto rappresentato e la sua percezione. La prospettiva aerea, infatti, poiché è abitualmente osservata nei paesaggi, conferisce alle Carceri la sensazione di immensità, nonostante l'esperienza suggerirebbe di vedere ambienti sempre più scuri in lontananza.

I motivi che possono aver spinto l'incisore all'uso della prospettiva aerea in modo poco consono possono essere di due ordini. Essendo spazi così complessi e articolati, non sottoposti a rigide regole prospettiche, la prospettiva aerea è determinante per una lettura comprensibile delle tavole. Dall'altro lato questo espediente non fa che confermare il linguaggio di sublime magnificenza con il quale Piranesi caratterizza tutte le sue incisioni, dalle rovine romane alle stesse Carceri: una sintassi fatta di prospettive con grandi architetture, bassi orizzonti, figure umane sottodimensionate e l'ingegnoso uso della prospettiva aerea per creare l'illusione di distanze amplificate.

Fig. 9. Prima (Invenzion capricciose di

Metropolitan Museum of Art, Washington) e seconda edizione (Carcer d'invenzione, Princeton University Art Museum) del frontespizio (sopra) e della tavola VII (sotto) delle Carceri piranesiane.
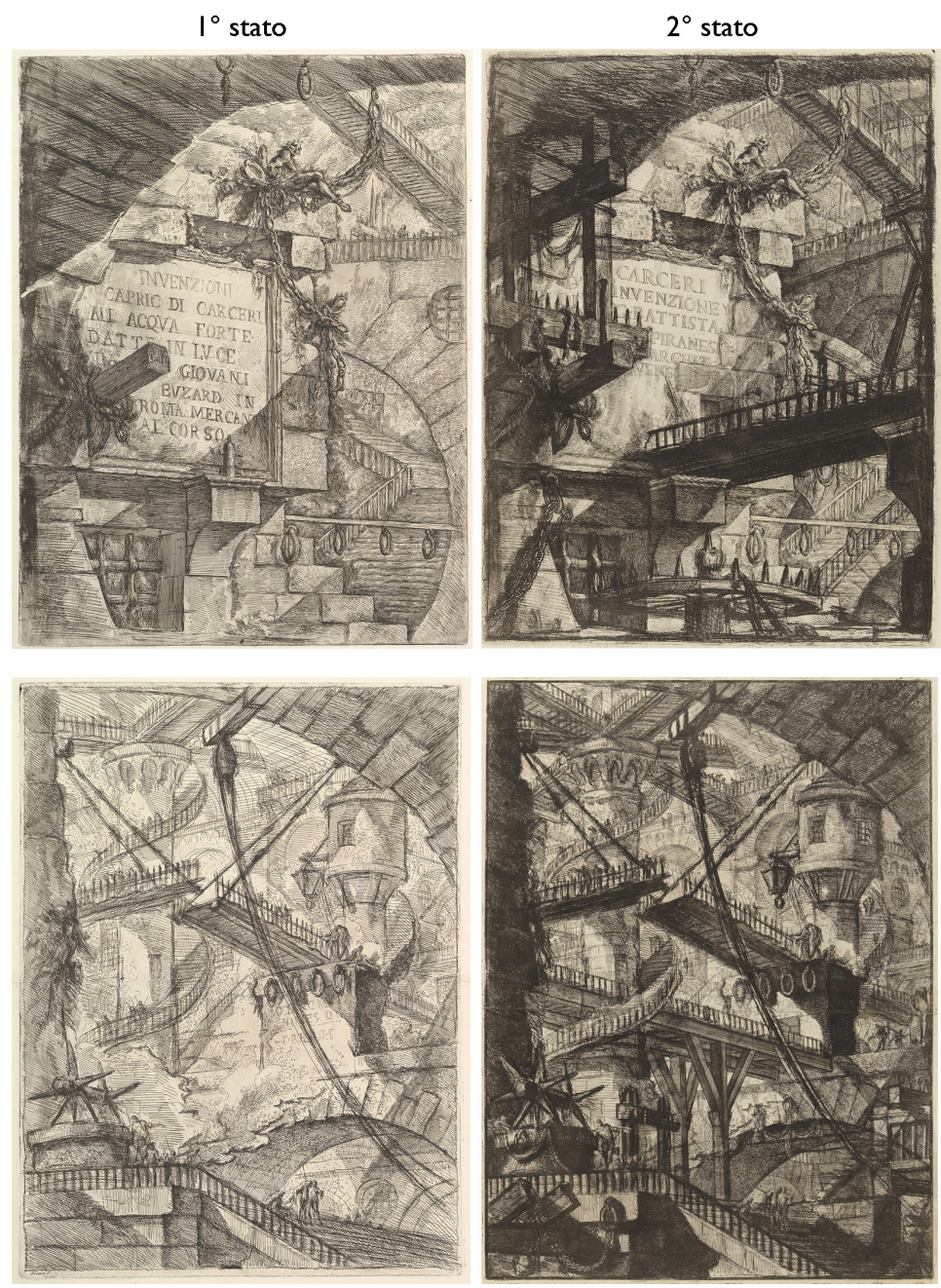

\section{Ringraziamenti}

L'autrice ringrazia i responsabili scientifici dell'accordo di collaborazione tra l'Istituto Centrale per la Grafica (M.C. Misiti, G. Scaloni, L. Ghedin) e il Dipartimento di Storia, Disegno e Restauro dell'Architettura (L. Carnevali, M. Fasolo, L. Baglioni) attraverso il quale è stata avviata la presente ricerca. 


\section{Note}

[I] In particolare, nella prima edizione le tavole che mostrano parti ambientate in esterno sono il frontespizio, la IV e la IX; nella seconda edizione la II, la IV, la V e la IX.

[2] "E quando hai a ffare le montagne che paiono più a lungi, più fa scuri i tuo colori; e quando le fai dimostrare più appresso, fa i colori più chiari". II passo è tratto dal capitolo LXXXV Del modo del colorire una montagna in fresco o in secco del Libro dell'arte di Cennini [Ricotta 2019, p. 202]. Questo passo e il successivo dell'Alberti (cfr. nota 3) affermano che la conseguenza cromatica della distanza sia lo scurirsi dell'oggetto. Ciò non è del tutto sbagliato, ma è sicuramente incompleto poiché, come preciserà Leonardo da Vinci nel capitolo Cll del Trattato della pittura: "Delle cose più oscure che l'aria, quella si dimostrerà di minor oscurità, la quale sia più remota: e delle cose più chiare che l'aria, quella si dimostrerà di minor bianchezza, che sarà più remota all'occhio: perche delle cose più chiare e più oscure che l'aria, in lunga distanza scambiando colore, la chiara acquista oscurità, e l'oscura acquista chiarrezza" [Leonardo da Vinci I65I, p. 26].

[3] Alberti, parlando dei raggi visuali afferma che "per molta distanzia indeboliscono; credo ne sia ragione che, carichi di lume e di colore, trapassano l'aere, quale, umido di certa grassezza, stracca i carichi razzi. Onde traemmo regola: quanto maggiore sarà la distanzia, tanto la veduta superficie parrà più fusca" [Alberti 20। I, pp. 21 17, 218 ].

[4] Della prospettiva aerea è il capitolo CLXV del Trattato della pittura in cui si legge: "Evvi un'altra prospettiva, la quale si dice aerea [...]. E da figurarsi un'aria un poco grossa. Tu fai che in simil aria l'ultime cose vedute in quella, come son le montagne, per la gran quantità dell'aria che si trova infra l'occhio tuo e dette montagne, paiono azzurre, quasi del color dell'aria, quando il sole è per levante" "Leonardo da Vinci I65 I, p. 45]. Nel capitolo CXLIX Prospettiva de' colori si legge: "I primi colori debbono essere semplici, \& i gradi della loro diminutione insieme con li gradi delle distanze si debbono convenire, cioè che le grandezze delle cose parteciperannò più della natura del punto quanto essi gli faran più vicini, \& i colori han tanto più a partecipare del colore del suo orizonte, quanto essi à quello son più propinquil" [Leonardo da Vinci I65 I, p. 39].

[5] Esistono diversi stati dei rami delle Carceri, oltre alla rielaborazione più evidente, che hanno apportato modifiche molto limitate. Questi stati sono illustrati in [Robinson 1986, pp. I39-210]. Nel presente studio si fa riferimento soltanto alle due principali edizioni.

\section{Riferimenti bibliografici}

Alberti L.B. (20। I). De pictura (redazione volgare). Firenze: Edizioni Polistampa.

Amoruso G. Firenze V.M. (20|4). Prospettiva del colore. Significati geometrici e cromatici nell'architettura di quadratura. In M. Rossi, V. Marchiafava (a cura di) Colore e colorimetria. Contributi multidisciplinari. Atti della decima Conferenza del Colore. Genova, | | - 12 settembre 20 |4. Sant'Arcangelo di Romagna (RN): Maggioli. vol. XA, pp. 69|-700.

Bell J.C.( 1 993).Zaccolini's theory of colorperspective.In TheArt Bulletin, n.75 ( I),pp.9 I - I 2.<https://doi.org/ | 0.2307/3045933> (consultato il 27 gennaio 202I).

Brooks K.R. (2017). Depth perception and the history of three-dimensional art: who produced the first stereoscopic images? In i-Perception, n. 8 ( I), pp. I-22. <https://doi.org/ I 0.1 I 77/204 I 6695 I 6680 I I 4> (consultato il 27 gennaio 202 I).

Ejzenštejn S.M. (1980). Piranesi o la fluidità delle forme. In M. Tafuri, La sfera e il labirinto. Avanguardie e architettura da Piranesi agli anni '70. Torino: Einaudi, pp. 89- I I0.

Garms J. ( I 982). Piranesi e la scenografia. In Schnapper A. (a cura di). La scenografia barocca. Bologna: Clueb, pp. I I7- I 22.

Gavuzzo-Stewart S. (1999). Nelle Carceri di G.B. Piranesi. Leeds: Northern University Press.

Guidolin F. (20 I5). Il colore della lontananza. Matteo Zaccolini, pittore e teorico di prospettiva. Tesi di dottorato in Storia delle Arti, tutor prof.ssa Martina Frank. Università Ca' Foscari Venezia.

Leonardo da Vinci ( 65 I). Trattato della pittura. Parigi: Giacomo Langlois.

Mancini M.F. (2015). Ragione e intuizione nell'illuminismo prospettico. Tesi di dottorato in Scienza della Rappresentazione e del Rilievo, tutor proff. L. De Carlo e R. Migliari. Sapienza Università di Roma.

Pane R. (1938). L'acquaforte di G.B. Piranesi. Napoli: Ricciardi.

Panofsky E. (1967). La vita e le opere di Albrecht Dürer. Milano: Feltrinelli.

Ricotta V. (2019). II Libro dell'arte di Cennino Cennini. Edizione critica e commento linguistico. Milano: FrancoAngeli.

Robison A. (1986). Piranesi. Early architectural fantasies. A catalogue raisonné of the etchings. Washington: National Gallery of Art.

\section{Autore}

Sofia Menconero, Sapienza Università di Roma, sofia.menconero@uniromal.it

Per citare questo capitolo: Menconero Sofia (202I). Distanze illusorie: l'uso della prospettiva aerea nelle Carceri piranesiane/llusory distances: the use of aerial perspective in Piranesi's Carceri. In In Arena A., Arena M., Mediati D., Raffa P. (a cura di). Connettere. Un disegno per annodare e tessere. Linguaggi Distanze Tecnologie. Atti del $42^{\circ}$ Convegno Internazionale dei Docenti delle Discipline della Rappresentazione/Connecting. Drawing for weaving relationship. Languages Distances Technologies. Proceedings of the $42^{\text {th }}$ International Conference of Representation Disciplines Teachers. Milano: FrancoAngeli, pp. $1760-1779$. 


\title{
Illusory Distances: the Use of Aerial Perspective in Piranesi's Carceri
}

\author{
Sofia Menconero
}

\section{Abstract}

In painting, aerial perspective is rendered through a decrease in colour saturation, contrast between parts and sharpness of details. In engraving, this effect goes beyond the chromatic component, and its rendering depends on the various techniques' execution characteristics. In general, the methods for obtaining tonal gradients in engraving techniques concern the distance, the crossing, and the thickness of the marks. The latter may depend on the use of tips of different thicknesses or, in the case of etching, on the number of multiple "stoppings-out".

The contribution presents a study on the aerial perspective in Piranesi's Carceri, conducted by breaking down the plates into planes of depth. The study shows how the Venetian artist applied this effect, which accentuates the depth and is usually applied to landscapes, in interior settings to increase the architecture's monumentality and illude the observer about greater distances.

\section{Keywords}

Piranesi, etching, Carceri, aerial perspective, illusory distance.
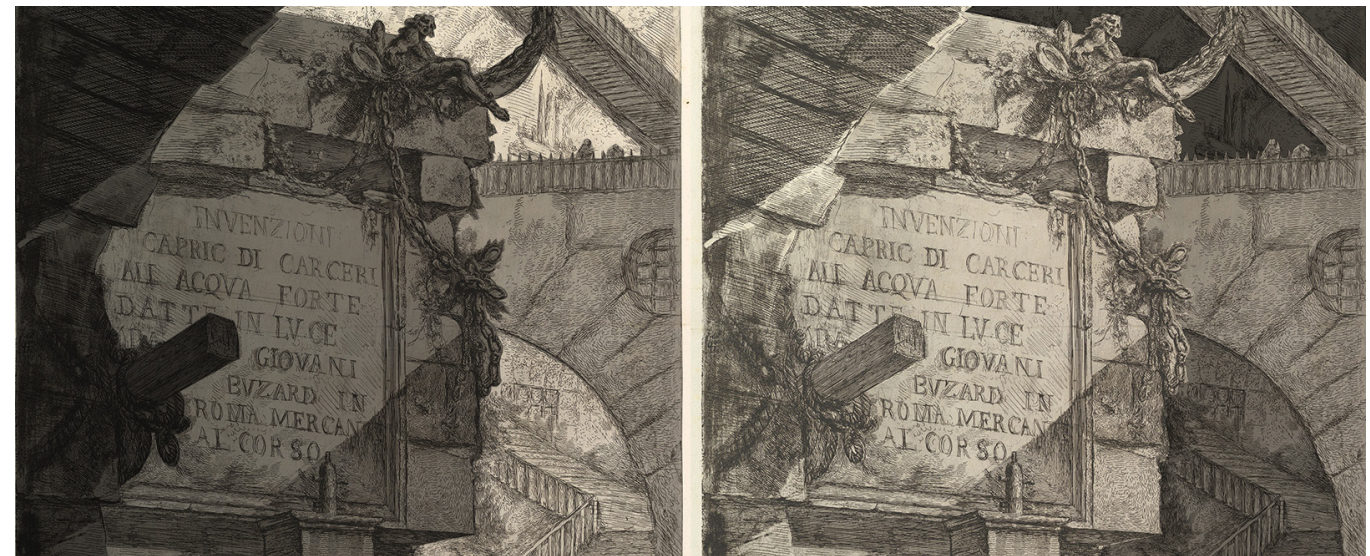


\section{Introduction}

Giovanni Battista Piranesi published the first edition of his famous prisons in the mid- 1700s: the Invenzioni capricciose di Carceri all'acquaforte [Robison 1986, pp. 37-44]. These are 14 particularly suggestive and singular plates, engraved with etching, which represent, with the typical free and brilliant lines of the Venetian engraving tradition, large rooms characterised by an ancient, massive, and spatially articulated architecture. Borrowing the topos of the prison as a courtyard or square from contemporary scenography [Gavuzzo-Stewart 1999, pp. 73-74], Piranesi's Carceri are characterised by an interpenetration of interior and exterior settings [Garms 1982, p. I 19] that go beyond the appearance of places of constraint and torture as they were in the $18^{\text {th }}$ century $[I]$.

Piranesi's technical treatment of his copper plates accentuates the expansion of space. Although the distances represented are not particularly large but are resolved within the architectural scale, he illudes observers into a deeper space using aerial perspective.

Some ten years after its first publication, Piranesi reworked his copper plates and published a new edition entitled Carceri d'invenzione [Robison 1986, pp. 45-53]. This new collection contains 16 plates, numbered and ordered by the author for the first time, of which two are entirely new (plate II and $\mathrm{V}$ ), one is almost wholly modified (plate $\mathrm{XVI}$ ), and the others show more or less evident variations. Apart from introducing new architectural elements and instrument of torture, an essential difference between the two editions concerns the broadening of the plates' tonal range, which gives more significant contrasts and an even more evident aerial perspective to the later version.

In addition to the vast literature that has honoured the Venetian engraver's work for centuries, this contribution aims to reflect on an aspect that is still little investigated: the use of aerial perspective in Piranesi's Carceri.

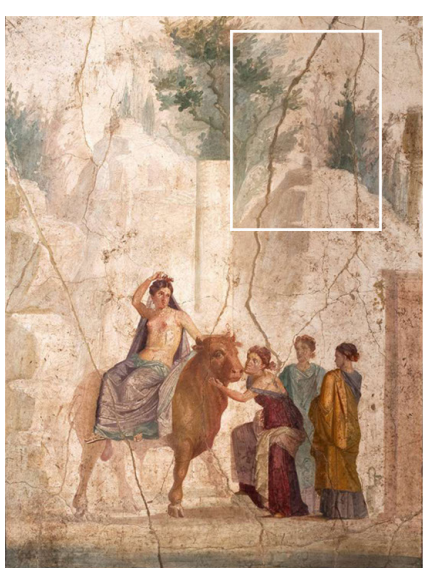

a

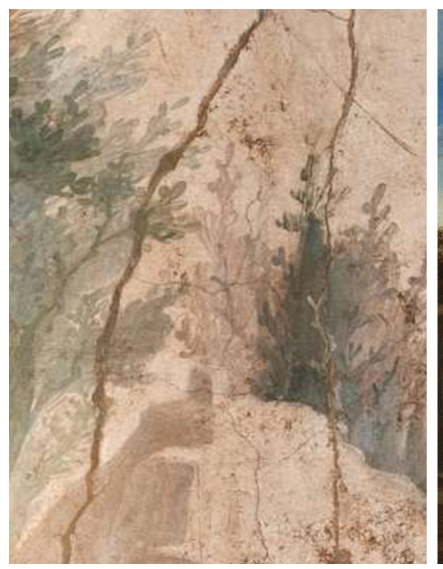

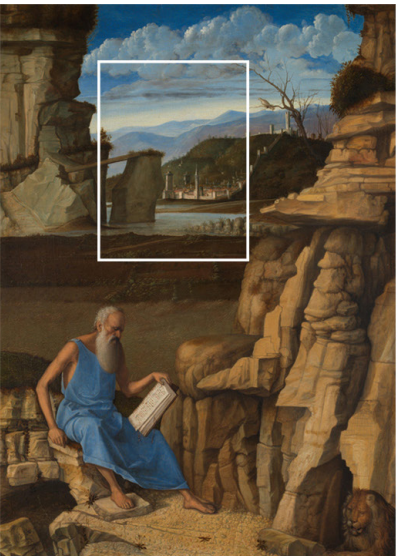

b

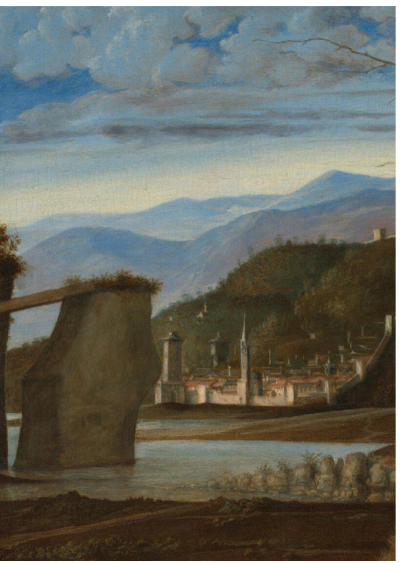

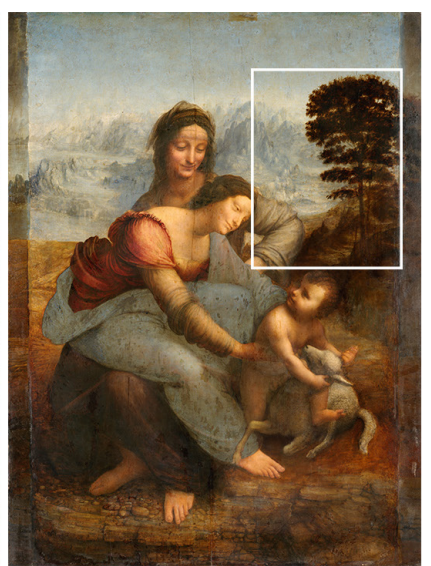

C

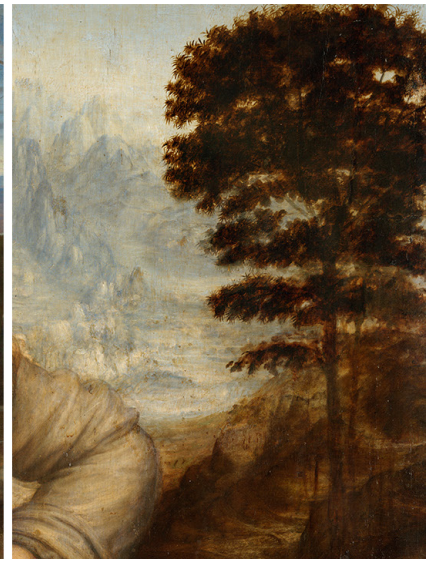

Fig. I. (a) Europa and the AD Nazionale di Napoli); (b) Giovanni Bellini, St. Jerome, oil on wood, I 48085 (National Gallery, London); (c) Leonardo Child with St.Anne, oil on wood, I503-19 (Musée du Louvre, Paris). 


\section{Aerial perspective from painting to etching}

Aerial perspective is one of the visual cues of depth [Brooks 20 I7, pp. I - I0]. It, along with other cues such as occlusion, relative size and density, field of view height, linear perspective, parallax, allows the brain to understand the location of a given observed feature. It is based on the assumption that there is an atmosphere composed of particles that alter vision as distance increases between the observer and the observed object, affecting colour saturation, contrast between parts and sharpness of details [Mancini 20I5, pp. 29-35].

In art, there is occasional evidence of the intuition of aerial perspective since the Roman period (fig. I a). In the Italian I $5^{\text {th }}$ century, there is a return to its assiduous use (fig. I b), even if the theorisation of the phenomenon or a shared practice to obtain it has not yet taken place, apart from incomplete hints by Cennino Cennini [2], in the previous century, and Leon Battista Alberti [3]. The first to study and define aerial perspective with the name we know today was Leonardo da Vinci in a series of notes that would flow into the posthumous Trattato della pittura (c. I540) [4]. As well as applying it in a masterly manner (fig. Ic), the Tuscan master also defined various phenomena that contribute to the visual clue of depth: "La prospettiva la quale si estende nella pittura si divide in tre parti principali, delle quali la prima è della diminutione che fanno le quantità de' corpi in diverse distanze. La seconda parte è quella che tratta della diminutione de' colori di tali corpi. La terza è quella che diminuisce la notizia delle figure, e de' termini che hanno essi corpi in varie distanze" [Leonardo da Vinci 1651, p. 104-105].

The chromatic effect of the distance will be taken up and deepened by Matteo Zaccolini in De colori [Guidolin 2015] and Prospettiva del colore (1622) [Bell 1993] and translated into mathematical terms by Johann Heinrich Lambert in Sur la perspective aërienne (I 774) [Mancini 20 I5, pp. I | 3- I I 5]. The blessed union between the science of projective geometry and the art of colour will have its most exciting application in illusory architecture, especially in the $17^{\text {th }}$ century with Andrea Pozzo [Amoruso, Firenze 20 I4; Mancini 20I5].

Fig. 2. (a) Albrecht Dürer The wire-drawing mill, watercolour and gouache on paper, I 489-94 (Sta(b) Albrecht Dürer Feost (b) Albrecht Dürer, Feast of Rose Garlands, oil on wood, 1506 (Photo (C) National Gallery Prague 2021)
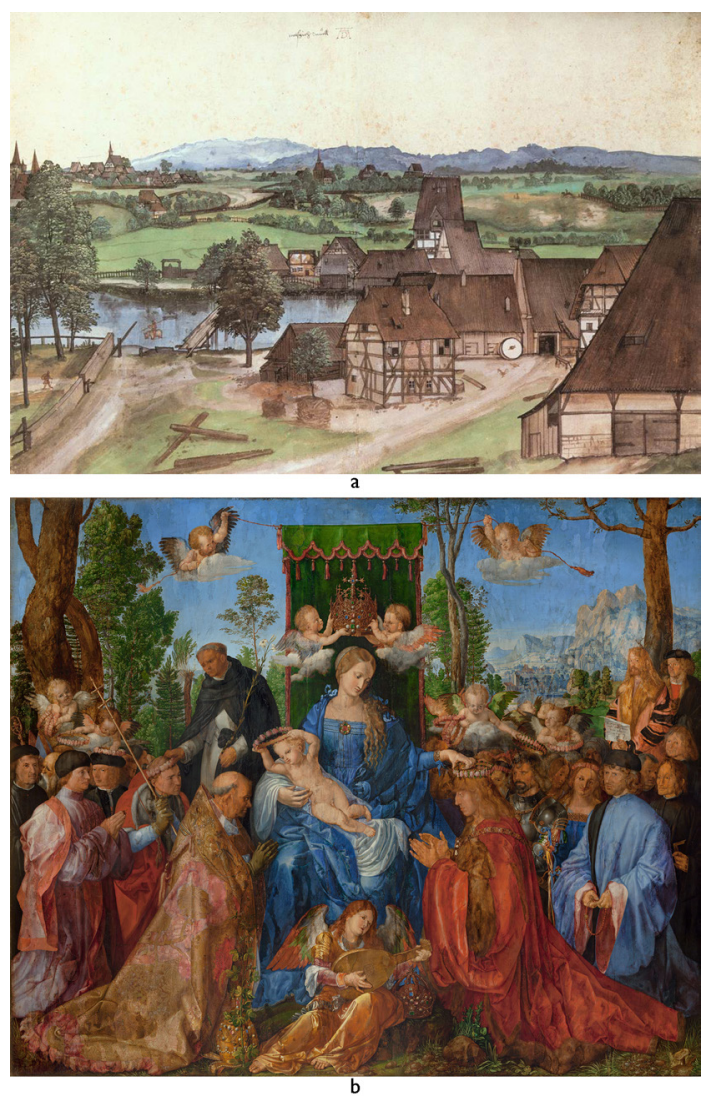
In the engraving technique, the phenomenon of aerial perspective is much less studied than in painting. The effect goes beyond the chromatic component and is rendered in terms of a loss of detail and tonal variation (lightening) of the representation's furthest areas.

The methods for rendering the aerial perspective in the engraving are closely linked to the engraving technique used. In this regard, the case of Albrecht Dürer is particularly emblematic because it allows a comparison of the rendering of aerial perspective carried out by the same author but with different techniques, both pictorial and engraving [Panofsky 1967]. In the watercolour The wire-drawing mill from c. I498 (fig. 2a), one of Dürer's earliest studies, the lack of perspective skills is partially compensated by the hint of an aerial perspective on the mountains in the background. It is achieved by progressive lightening, a simplification of the details and a blue hue. Remaining within the pictorial sphere, the Feast of Rose Garlands (fig, 2b), oil on wood dated I506, shows the splendid richness of the Venetian-influenced colour accompanied by an aerial perspective characterised by progressively lighter and bluer tones. The detail in the background is relatively significant, following the general accuracy of the drawing.

The engravings by Dürer considered are a burin, the Virgin with the dragonfly from around I 493 (fig. 3a), and a woodcut from the same years, Samson rending the lion (fig. 3b). The differences in aerial perspective treatment mainly depend on the expressive possibilities that the two techniques allow: "an engraver tends to be analytical, detailed and concrete as much as a woodcutter tends to be synoptic, concise and abstract" [transl. from Panofsky 1967, p. 85]. Both techniques render aerial perspective through the lightning of tones and the loss of detail. The engraving with a burin shows hills in the distance that are less detailed than the rest of the composition. The outlines of these hills can be made out, and some other shading helps understand the orography. In the woodcut, the hills in the background are only represented by their outlines.

Generally speaking, the methods for obtaining tonal gradient in engraving techniques concern the distance and intersection of the lines (fig. 4a) and their thickness. The latter can depend on the use of tips of different thickness (fig. 4b) or, in the case of etching, on the number of multiple "stoppings-out" (morsure) (fig. 4c). This indirect engraving technique allows the execution, using an acid called acquaforte, of multiple 'stoppings-out' that will be among the reason for the extraordinary tonal variety of Piranesi's Carceri [Pane 1938, pp. 23-24].

Fig. 3. (a) Albrecht Dürer, Virgin with the dragonfly, engraving (print), 1493-97 (Rijksmuseum, Amsterdam) (b) Albrecht Dürer, Samson rending the lion, woodcut (print), 1494-98 (Rijksmuseum, Amsterdam).

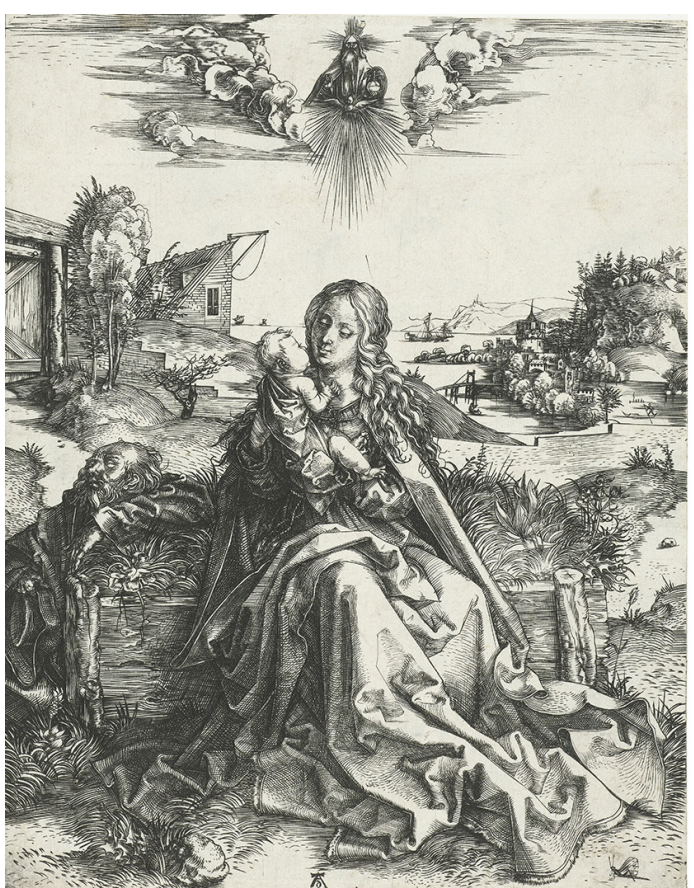

a

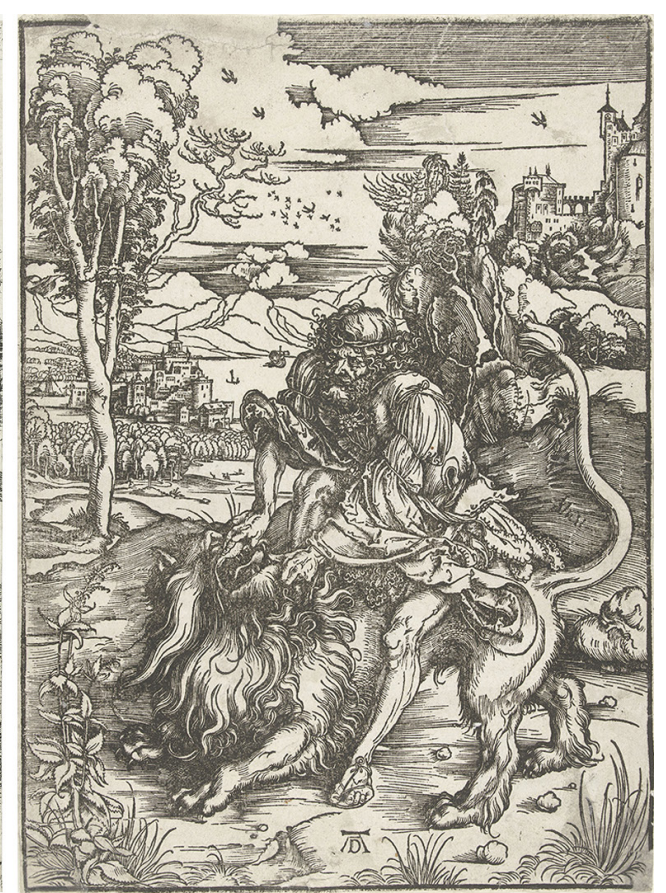

b 
Fig. 4. Giovanni Battista Pranesi, details from The man on the Rack, plate II of Carceri d'invenzione, etching and engraving (copper plate), |749-6| (Istituto Centrale per la Grafica Roma).Various ways of rendering tonal gradients: (a) spacing and crossing of nes: (b) tips of different thickness; (c) multiple 'stoppings-out'.
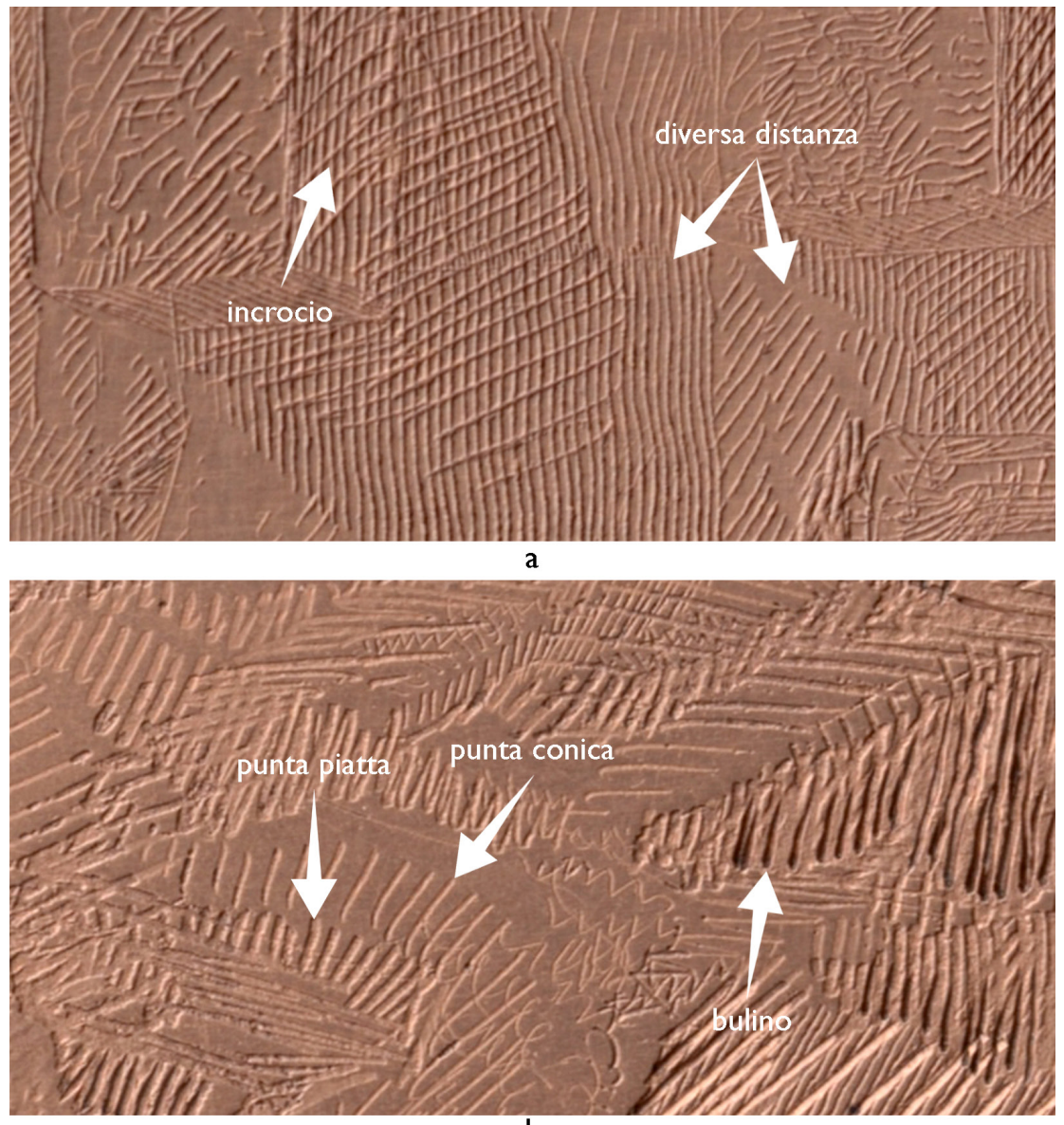

b

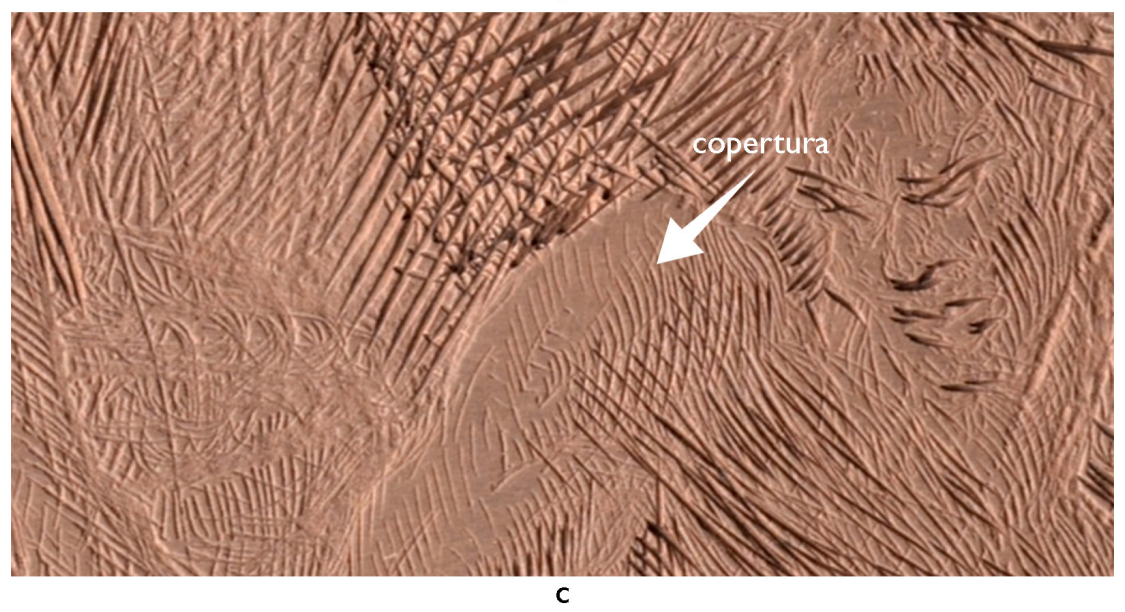

\section{Reflections on the apparent depth of Piranesi's Carceri}

Piranesi's Carceri are perspectives constructed without the projective rigour that would allow the spaces represented to be known through the method of perspective restitution. However, the spaces can be interpreted through other analyses.

One of these analyses involves breaking down the plates into depth planes, as if they were backdrops or stage flats, to provide an idea of the spatial relationship between the elements represented, at least in relative terms. This operation is carried out by intervening where solutions of continuity between groups of architectural elements are visible. Sergej 
Ejzenštejn had already observed the singular discontinuity of the perspectives of the Carceri: "Nowhere in the Carceri do we find an uninterrupted perspective view into the depths. But everywhere the initial movement of deepening perspective is interrupted by a bridge, a column, an arch, a passage. Each time behind such a column or semicircle of an arch the perspective movement is caught up again. However, it is not in the same perspective mode but in a new one: usually in a much more reduced scale of representation than you would expect or might suggest" [transl. from Ejzenštejn 1980, p. I06].

The cases given as examples, which concern the first edition of the frontispiece and plate $\mathrm{VII}$, show the division into five planes of depth.

In the frontispiece (fig. 5), the foreground includes the stone arch that frames the upper left margin. Immediately after comes the complex with the epigraph and the prisoner. Further on is the stone bridge on the right and the wooden footbridge above it. The fourth plane concerns the staircase below the bridge, and the last plane involves the background above, towards the sky.

The foreground of plate VII (fig. 6) is again an arch, this time framing the plate in the upper right corner and from the top of which a rope descends. Next is the large staircase with the well and the wall behind it. Further on is the stone bridge with the epigraph and the wood-

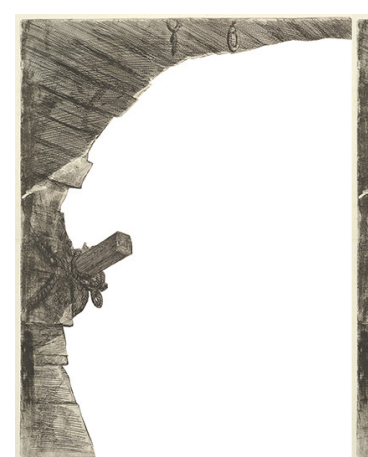

$1^{\circ}$ piano

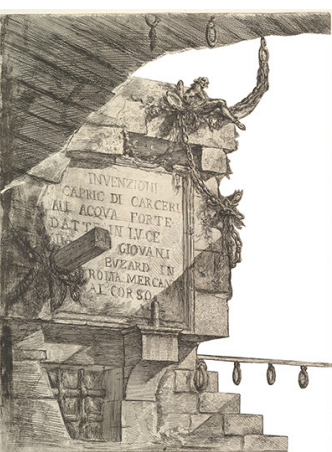

$2^{\circ}$ piano

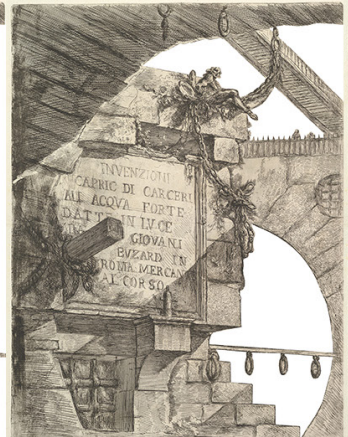

$3^{\circ}$ piano

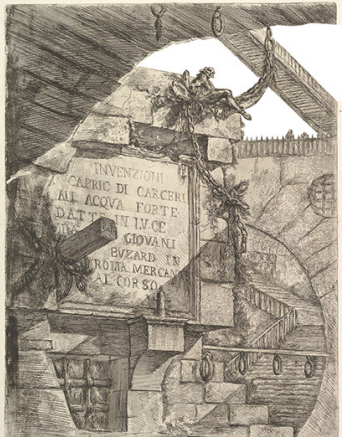

$4^{\circ}$ piano
Fig. 5. Giovanni Battista Invenzioni capricciose Carceri all'acquaforte, etching (print), I 749- 1750

(Metropolitan Museum

of Art, Washington):

breakdown into depth planes.

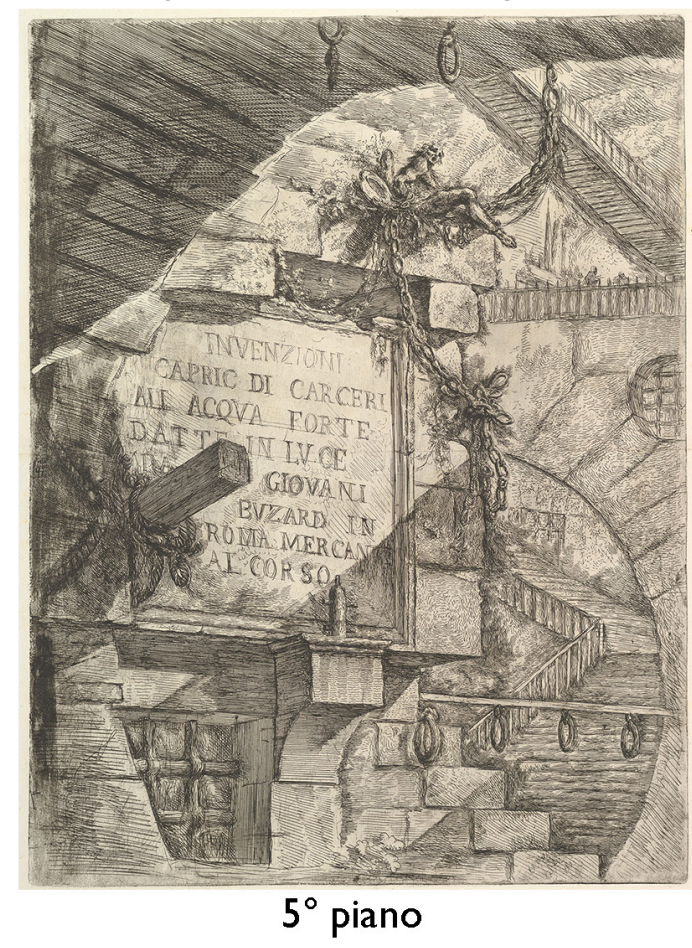

$5^{\circ}$ piano 
en drawbridge. Then there is a group of various architectures, including the two towers with the spiral staircase. Finally, a background that looks like an interior.

It is possible to extend this type of study to the other plates in the series: what recurs is the presence of a foreground created by an element that frames the plate, a sort of proscenium arch treated in darker tones than the rest. Another element contributing to the definition of the planes of depth is the graphic treatment associated with the various parts of the images. As the depth increases, the marks engraved in the etching become less close together and fewer in number and less defined.

A synthesis figure was created, where a different brightness was attributed to each plane, to highlight and synthesise the planes of depth found in the two plates examined. In the first case (fig. 7), the assigned brightness amplifies, but follows, the aerial perspective given by Piranesi, and it is evident how, in this way, the perception of the spaces makes one think of external settings. In the second case (fig. 8), the brightness is assigned oppositely: the planes become darker in the distance, as should happen in a closed environment subject to ambient occlusion. In this second case, the spaces are perceptually smaller.

Ten years after the first etchings, the engraver took the old copper plates and modified them, removing and adding lines [5]. The resulting prints are more contrasty, with deeper darks that further accentuate the aerial perspective (fig. 9).

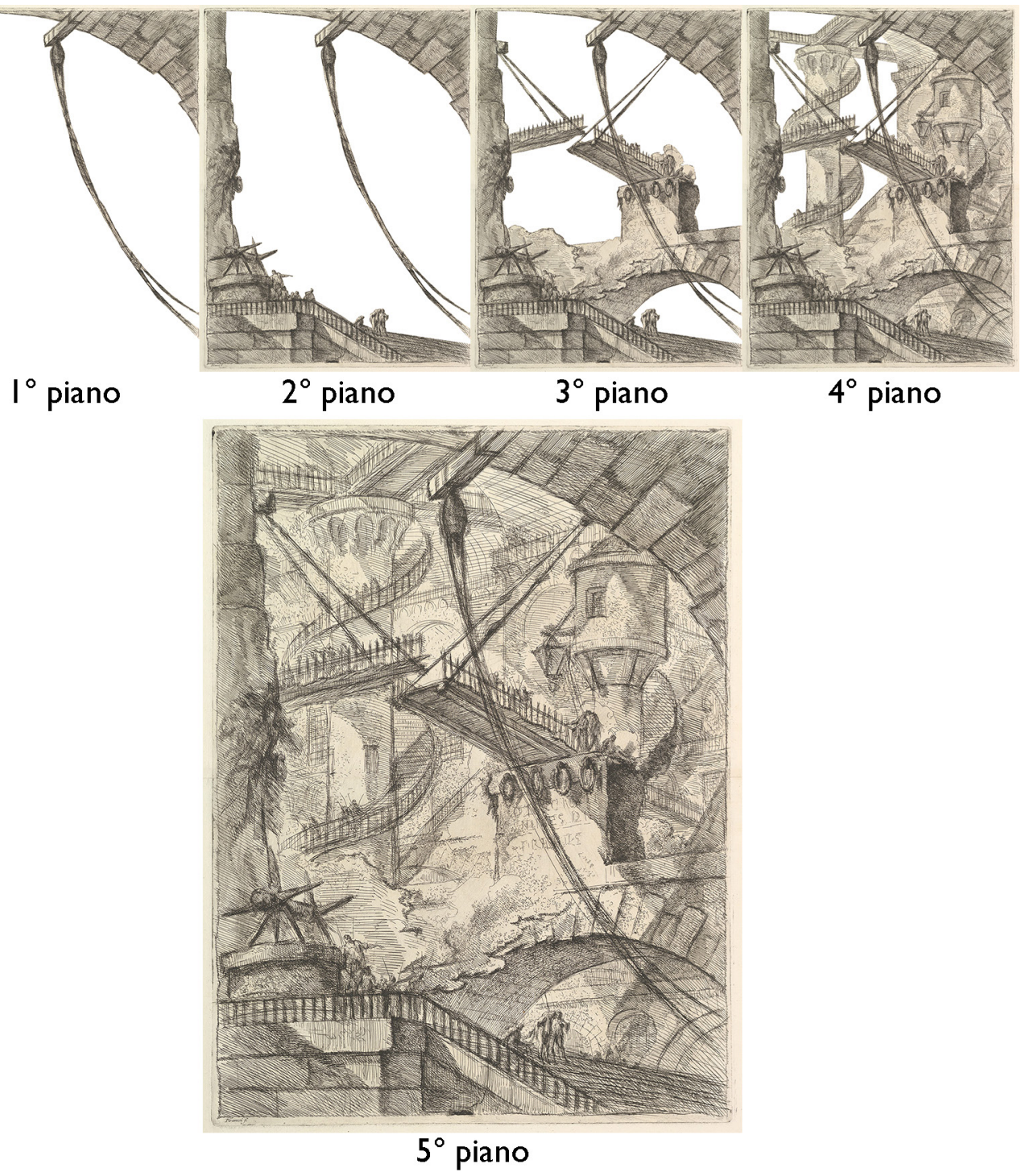


Fig. 7. Graphic

elaboration of the

frontispiece (left) and

plate VII (right) of

Carceri ani" capricciose di

eri all'acquaforte. The

processing accentuates

given by Piranesi.
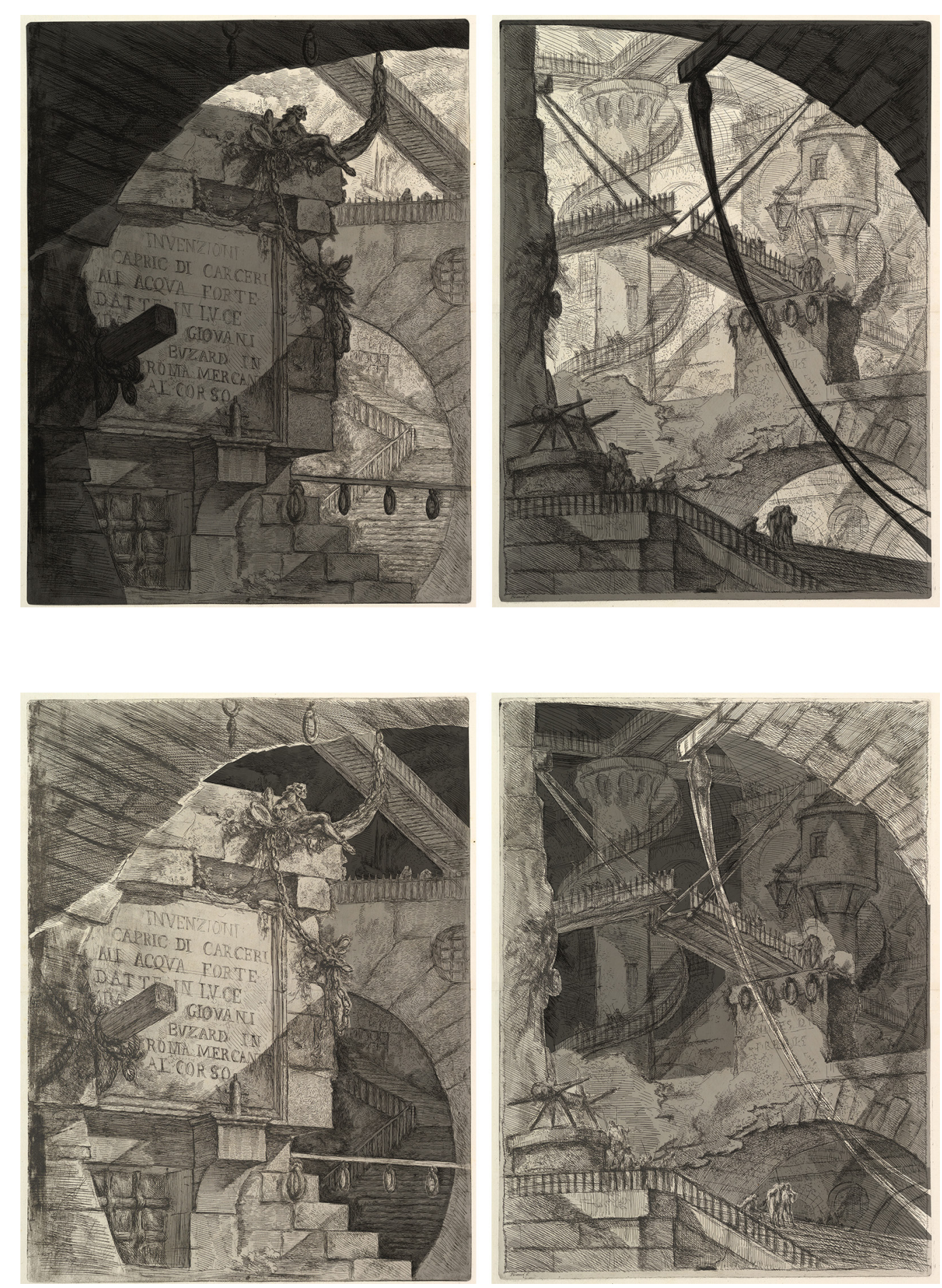

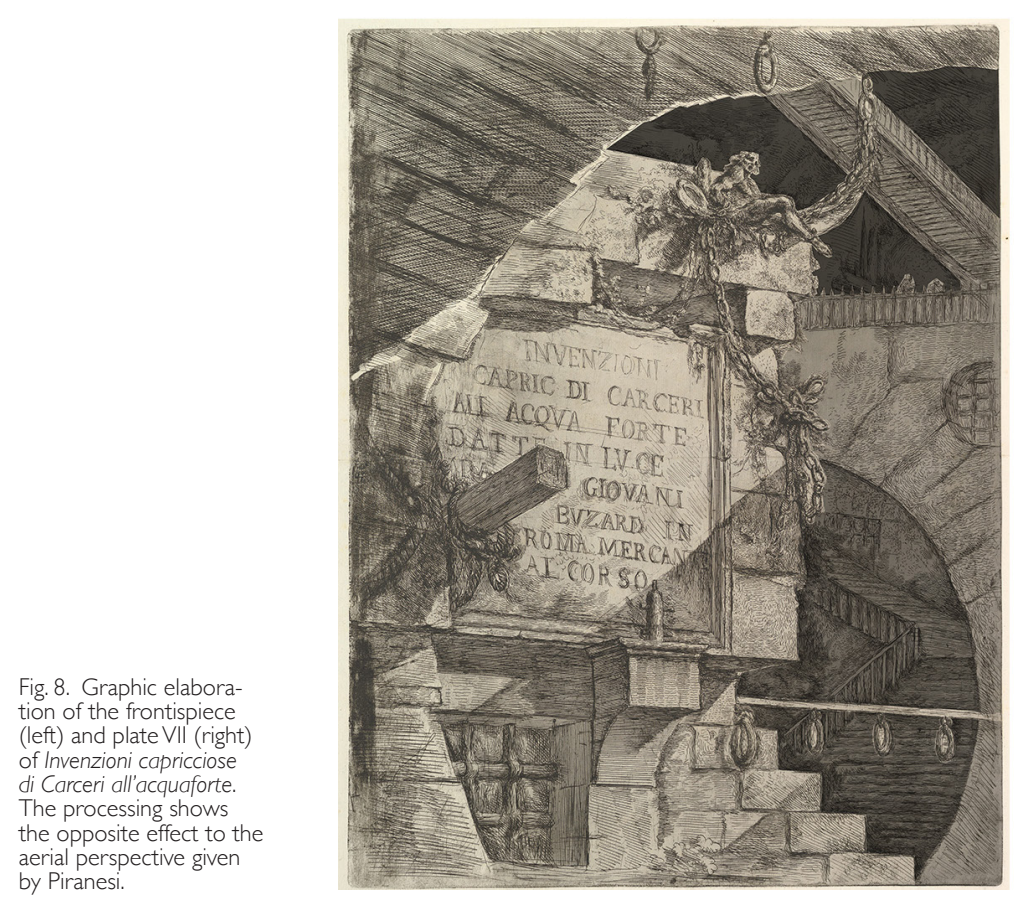

Fig. 8. Graphic elaboration of the frontispiece (left) and plate VII (right) of Invenzioni capriccios di Carceri all'acquaforte. The processing shows aerial perspective given by Piranesi. 


\section{Conclusions}

Piranesi's effect to his Carceri consists of assigning lighter tones as distance increases in line with aerial perspective principles, even though the environments are supposed to represent interior spaces, dark and underground, in which light does not have the strength to cross great distances. This effect leads to an inconsistency between the represented subject and its perception. As it is usually observed in landscapes, the aerial perspective gives the Carceri a feeling of immensity, although experience would suggest seeing darker environments in the distance.

There are two main reasons why the engraver may have misused the aerial perspective. Because the spaces are so complex and articulated and are not subject to the rigid rules of linear perspective, the aerial perspective is crucial for a comprehensible reading of the plates. On the other hand, this expedient only confirms the language of sublime magnificence with which Piranesi characterises all his works, from the Roman ruins to the Carceri themselves: a syntax made up of perspectives with great architectures, low horizons, little human figures and the ingenious use of aerial perspective to create the illusion of amplified distances.
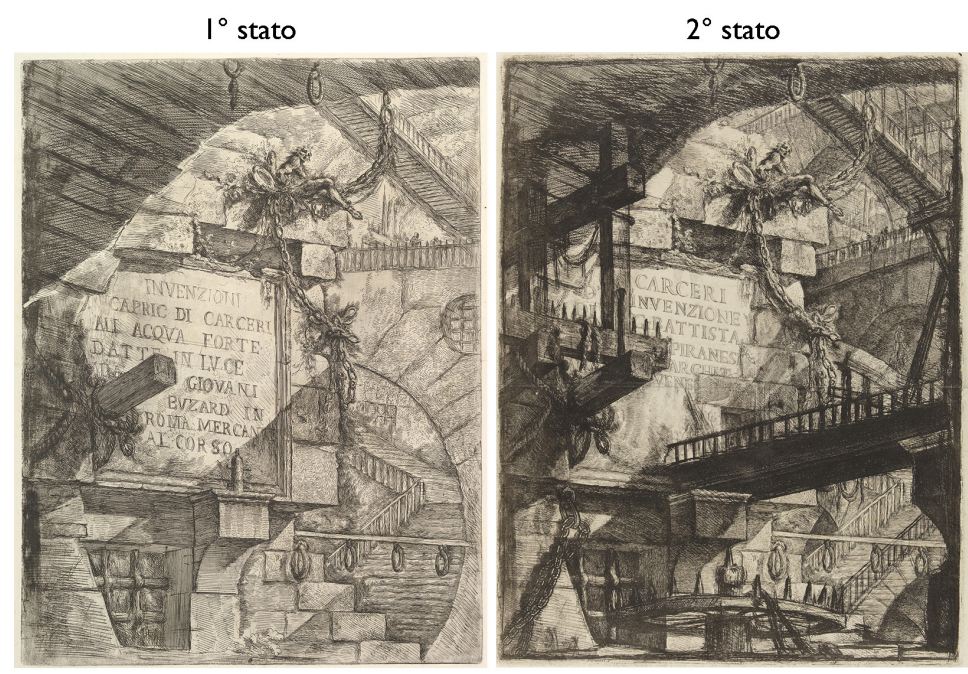

Fig. 9. First (Invenzioni capricciose di Carcer all'acquaforte,

Metropolitan Museum of Art, Washington) and second edition (Carcer d'invenzione, Princeton University Art Museum) of frontispiece (above) and plate VII (below) of Piranesi's Carceri.
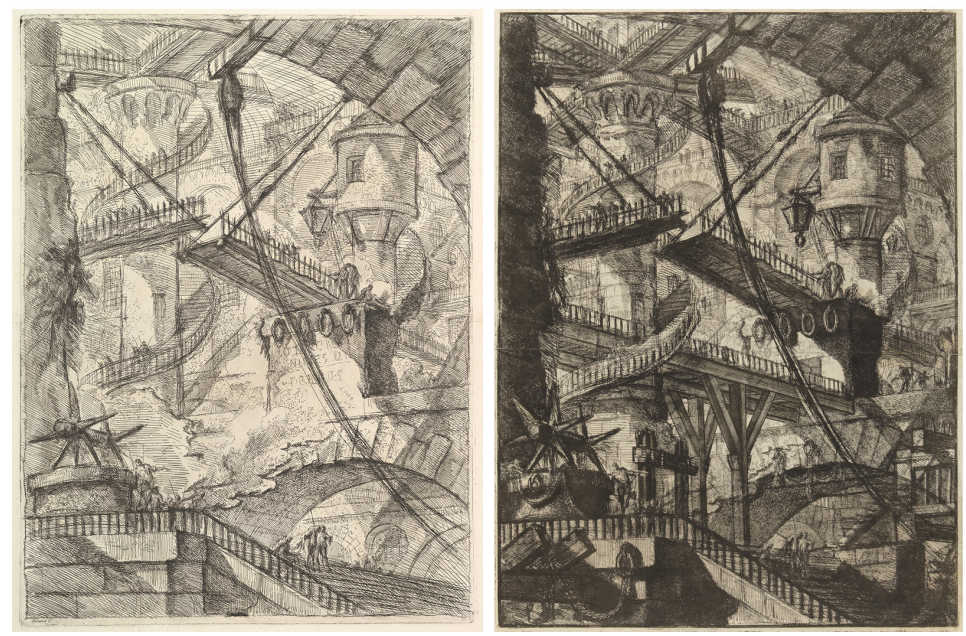

\section{Acknowledgements}

The author would like to thank the scientific coordinators of the collaboration agreement between the Istituto Centrale per la Grafica (M.C. Misiti, G. Scaloni, L. Ghedin) and the Department of History, Representation and Restoration of Architecture (L. Carnevali, M. Fasolo, L. Baglioni) through which this research was initiated. 


\section{Notes}

$[I]$ In particular, in the first edition, the plates showing parts set outdoors are the frontispiece, IV and IX; in the second edition, II, IV,V and IX.

[2] "E quando hai a ffare le montagne che paiono più a lungi, più fa scuri i tuo colori; e quando le fai dimostrare più appresso, fa i colori più chiari". The passage is taken from chapter $L X X X V$ Del modo del colorire una montagna in fresco o in secco of Cennini's Libro dell'arte [Ricotta 2019, p. 202]. This passage and the following one by Alberti (cf. footnote 3) state that the chromatic consequence of distance is the darkening of the object. This is not entirely wrong, but it is certainly incomplete, since, as Leonardo da Vinci pointed out in chapter Cll of the Trattato della pittura: "Delle cose più oscure che l'aria, quella si dimostrerà di minor oscurità, la quale sia più remota: e delle cose più chiare che l'aria, quella si dimostrerà di minor bianchezza, che sarà più remota all'occhio: perche delle cose più chiare e più oscure che l'aria, in lunga distanza scambiando colore, la chiara acquista oscurità, e l'oscura acquista chiarrezza" [Leonardo da Vinci I65 I, p. 26].

[3] Alberti, speaking of visual rays, affirms that "per molta distanzia indeboliscono; credo ne sia ragione che, carichi di lume e di colore, trapassano l'aere, quale, umido di certa grassezza, stracca i carichi razzi. Onde traemmo regola: quanto maggiore sarà la distanzia, tanto la veduta superficie parrà più fusca" [Alberti 201 I, pp. 217-218].

[4] Della prospettiva aerea is the chapter CLXV of the Trattato della pittura in which we read: "Ewvi un'altra prospettiva, la quale si dice aerea $[. .$.$] . E da figurarsi un'aria un poco grossa. Tu fai che in simil aria l'ultime cose vedute in quella, come son le montagne,$ per la gran quantità dell'aria che si trova infra l'occhio tuo e dette montagne, paiono azzurre, quasi del color dell'aria, quando il sole è per levante" [Leonardo da Vinci I65 I, p. 45]. In the chapter CXLIX Prospettiva de' colori we read: "I primi colori debbono essere semplici, \& i gradi della loro diminutione insieme con li gradi delle distanze si debbono convenire, cioè che le grandezze delle cose parteciperannò più della natura del punto quanto essi gli faran più vicini, \& i colori han tanto più a partecipare del colore del suo orizonte, quanto essi à quello son più propinqui"' [Leonardo da Vinci I65I, p. 39].

[5] In addition to the best-known reworking, there are several states of the copper plates of the Carceri, which have made minimal changes. These states are illustrated in [Robison 1986, pp I39-210]. In the present study, reference is made only to the two main editions.

\section{References}

Alberti L.B. (20। I). De pictura (redazione volgare). Firenze: Edizioni Polistampa.

Amoruso G. Firenze V.M. (20|4). Prospettiva del colore. Significati geometrici e cromatici nell'architettura di quadratura. In M. Rossi, V. Marchiafava (a cura di) Colore e colorimetria. Contributi multidisciplinari. Atti della decima Conferenza del Colore. Genova, | I - 12 settembre 20 |4. Sant'Arcangelo di Romagna (RN): Maggioli. vol. XA, pp. 69 |-700.

Bell J.C.( I 993).Zaccolini's theory of colorperspective. In TheArt Bulletin, n.75 ( I), pp.9 I - I I . <https://doi.org/ 0.2307/3045933> (accessed 2021, January 27).

Brooks K.R. (2017). Depth perception and the history of three-dimensional art: who produced the first stereoscopic images? In i-Perception, n. 8 (I), pp. I-22. <https://doi.org/I0.1 I 77/204 I6695 I 6680 I I 4> (accessed 202 I, January 27).

Ejzenštejn S.M. (1980). Piranesi o la fluidità delle forme. In M. Tafuri, La sfera e il labirinto. Avanguardie e architettura da Piranesi agli anni '70. Torino: Einaudi, pp. 89- I 10.

Garms J. (1982). Piranesi e la scenografia. In Schnapper A. (a cura di). La scenografia barocca. Bologna: Clueb, pp. I I 7 - I 22.

Gavuzzo-Stewart S. (1999). Nelle Carceri di G.B. Piranesi. Leeds: Northern University Press.

Guidolin F. (20 I5). Il colore della lontananza. Matteo Zaccolini, pittore e teorico di prospettiva. Tesi di dottorato in Storia delle Arti, tutor prof.ssa Martina Frank. Università Ca' Foscari Venezia.

Leonardo da Vinci ( 65 I). Trattato della pittura. Parigi: Giacomo Langlois.

Mancini M.F. (2015). Ragione e intuizione nell'illuminismo prospettico. Tesi di dottorato in Scienza della Rappresentazione e del Rilievo, tutor proff. L. De Carlo e R. Migliari. Sapienza Università di Roma.

Pane R. (1938). L'acquaforte di G.B. Piranesi. Napoli: Ricciardi.

Panofsky E. (1967). La vita e le opere di Albrecht Dürer. Milano: Feltrinelli.

Ricotta V. (2019). II Libro dell'arte di Cennino Cennini. Edizione critica e commento linguistico. Milano: FrancoAngeli.

Robison A. (1986). Piranesi. Early architectural fantasies. A catalogue raisonné of the etchings. Washington: National Gallery of Art.

Author

Sofia Menconero, Sapienza Università di Roma, sofia.menconero@uniromal.it

To cite this chapter. Menconero Sofia (202I). Distanze illusorie: l'uso della prospettiva aerea nelle Carceri piranesiane/llusory distances: the use of aerial perspective in Piranesi's Carceri. In Arena A., Arena M., Mediati D., Raffa P. (a cura di). Connettere. Un disegno per annodare e tessere. Linguaggi Distanze Tecnologie. Atti del $42^{\circ}$ Convegno Internazionale dei Docenti delle Discipline della Rappresentazione/Connecting. Drawing for weaving relationship. Languages Distances Technologies. Proceedings of the $42^{\text {th }}$ International Conference of Representation Disciplines Teachers. Milano: FrancoAngeli, pp. $1760-1779$. 